\title{
Epac Signaling Is Required for Cocaine-Induced Change in AMPA Receptor Subunit Composition in the Ventral Tegmental Area
}

\author{
Xiaojie Liu, ${ }^{1}$ Yao Chen, ${ }^{1}$ Jiaqing Tong, ${ }^{1,2}$ @Ashley M. Reynolds, ${ }^{1}$ Sarah C. Proudfoot, ${ }^{1}$ Jinshun Qi, ${ }^{2}$ Peter Penzes, ${ }^{3}$ \\ Youming $\mathrm{Lu},{ }^{4,5}$ and ${ }^{10}$ Qing-song Liu ${ }^{1}$ \\ ${ }^{1}$ Department of Pharmacology and Toxicology, Medical College of Wisconsin, Milwaukee, Wisconsin 53226, ${ }^{2}$ Department of Physiology, Shanxi Medical \\ University, Taiyuan 030001, China, ${ }^{3}$ Departments of Physiology and Psychiatry and Behavioral Sciences, Northwestern University Feinberg School of \\ Medicine, Chicago, Illinois 60611, ${ }^{4}$ Neuroscience Center of Excellence and Department of Neurology, Louisiana State University School of Medicine, New \\ Orleans, Louisiana 70112, and 5epartment of Pathophysiology, Tongji Medical College and Institute for Brain Research, Huazhong University of Science \\ and Technology, Wuhan 430030, China
}

Exchange protein directly activated by cAMP (Epac) and protein kinase A (PKA) are intracellular receptors for cAMP. Although PKA and its downstream effectors have been studied extensively in the context of drug addiction, whether and how Epac regulates cellular and behavioral effects of drugs of abuse remain essentially unknown. Epac is known to regulate AMPA receptor (AMPAR) trafficking. Previous studies have shown that a single cocaine exposure in vivo leads to an increase in GluA2-lacking AMPARs in dopamine neurons of the ventral tegmental area (VTA). We tested the hypothesis that Epac mediates cocaine-induced changes in AMPAR subunit composition in the VTA. We report that a single cocaine injection in vivo in wild-type mice leads to inward rectification of EPSCs and renders EPSCs sensitive to a GluA2-lacking AMPAR blocker in VTA dopamine neurons. The cocaine-induced increase in GluA2-lacking AMPARs was absent in Epac2-deficient mice but not in Epac1-deficient mice. In addition, activation of Epac with the selective Epac agonist 8-CPT-2Me-cAMP (8-CPT) recapitulated the cocaine-induced increase in GluA2-lacking AMPARs, and the effects of 8-CPT were mediated by Epac2. We also show that conditioned place preference to cocaine was impaired in Epac2-deficient mice and in mice in which Epac2 was knocked down in the VTA but was not significantly altered in Epac1-deficient mice. Together, these results suggest that Epac2 is critically involved in the cocaine-induced change in AMPAR subunit composition and drug-cue associative learning.

Key words: AMPAR trafficking; cocaine; conditioned place preference (CPP); Epac signaling; inward rectification

\section{Significance Statement}

Addictive drugs, such as cocaine, induce long-lasting adaptions in the reward circuits of the brain. A single intraperitoneal injection of cocaine leads to changes in the composition and property of the AMPAR that carries excitatory inputs to dopamine neurons. Here, we provide evidence that exchange protein directly activated by cAMP (Epac), a cAMP sensor protein, is required for the cocaine-induced changes of the AMPAR. We found that the effects of cocaine were mimicked by activation of Epac but were blocked by genetic deletion of Epac. Furthermore, cocaine-cue associative learning was impaired in mice lacking Epac. These findings uncovered a critical role of Epac in regulating the cellular and behavioral actions of cocaine.

\section{Introduction}

The rewarding and reinforcing effects of cocaine are primarily mediated by enhanced dopaminergic transmission in the me- solimbic dopamine system (Anderson and Pierce, 2005). Dopamine $D_{1}$ and $D_{2}$ receptors are G-protein-coupled receptors, the activation of which leads to changes in intracellular cAMP levels 
(Neve et al., 2004; Anderson and Pierce, 2005; Tritsch and Sabatini, 2012). cAMP activates intracellular effectors: the classic protein kinase A (PKA) and the recently discovered exchange protein directly activated by cAMP (Epac; Cheng et al., 2008; Gloerich and Bos, 2010; Schmidt et al., 2013). PKA and its downstream effectors have been examined extensively in the context of drug addiction (Anderson and Pierce, 2005). However, whether and how Epac regulates cellular and behavioral effects of drugs of abuse remain essentially unknown. Epac is known to mediate many physiological and pathological functions, including insulin secretion, gene transcription, neurotransmitter release, AMPA receptor (AMPAR) trafficking, integrin-mediated cell adhesion, cell survival and apoptosis, and hippocampus-dependent learning and memory (for review, see Gloerich and Bos, 2010). Two genes, Epac1 and Epac2, encode Epac proteins. Epac2 is expressed predominately in the brain, whereas Epac1 is expressed ubiquitously in many tissues but its expression in the brain is very low (Kawasaki et al., 1998; de Rooij et al., 1998). Epac2 ${ }^{-/-}$mice exhibit deficits in social interaction and communication but normal locomotor activity and working and reference memory (Srivastava et al., 2012). There is also evidence for functional redundancy between Epac1 and Epac2, because Epac double knock-out mice (Epac ${ }^{-/-}$) show deficits in hippocampal longterm potentiation (LTP), social interaction, and spatial learning and memory. However, neither Epac1 ${ }^{-1-}$ nor Epac2 ${ }^{-/-}$mice exhibit these phenotypes (Yang et al., 2012). Given its important roles in synaptic transmission in learning and memory, Epac is well positioned to regulate drug-induced synaptic plasticity and reinforcement learning.

A single cocaine injection in vivo in rats or mice led to an increase in surface GluA2-lacking AMPARs in ventral tegmental area (VTA) dopamine neurons ex vivo (Bellone and Lüscher, 2006; Good and Lupica, 2010). GluA2-lacking AMPARs exhibit higher single-channel conductance and calcium permeability than GluA2-containing AMPARs (Mameli et al., 2007). A cocaine-induced increase in GluA2-lacking AMPARs in the VTA may contribute to the increase in the AMPAR/NMDAR ratio (Ungless et al., 2001; Borgland et al., 2004; Liu et al., 2005; Bellone and Lüscher, 2006; Mameli et al., 2007, 2009; Argilli et al., 2008) and LTP at hyperpolarizing membrane potentials (Mameli et al., 2011). Repeated cocaine injections render adaptions in the VTA persistent, which triggers adaptions downstream in the nucleus accumbens (Kourrich et al., 2007; Conrad et al., 2008; Huang et al., 2009; Mameli et al., 2009). The cocaine-induced increase in GluA2-lacking AMPARs depends on neuronal activity, dopamine transporter, and the $\mathrm{D}_{1}$ dopamine receptor (Argilli et al., 2008; Brown et al., 2010). However, how $\mathrm{D}_{1}$ receptor activation leads to an increase in GluA2-lacking AMPARs remains poorly understood. Epac is a downstream effector of $D_{1}$ receptors (Woolfrey et al., 2009). Epac2 is coimmunoprecipitated with GluA2/3 but not with GluA1, and the selective Epac agonist 8-CPT-2Me-cAMP (8-CPT) induces removal of GluA2/3 AMPARs in cultured cortical neurons (Woolfrey et al., 2009). 8-CPT-induced synaptic modification in hippocampal slices was blocked by an interference peptide that disrupts the interaction between GluA2 and postsynaptic PDZ proteins (Ster et al., 2009). We hypothesize that Epac mediates the cocaine-induced increase in GluA2-lacking AMPARs in VTA dopamine neurons. We tested this hypothesis by using mice in which one or both of these genes are deleted (Yang et al., 2012). We show that Epac2, but not Epac1, is required for the cocaine-induced increase in GluA2lacking AMPARs in VTA dopamine neurons. Moreover, we have found that conditioned place preference (CPP) to cocaine was impaired in Epac2-deficient mice. Our studies reveal a critical role of Epac in regulating cocaine-induced long-term synaptic plasticity and drug-cue associative learning.

\section{Materials and Methods}

Animals. Animal maintenance and use were in accordance with protocols approved by the Institutional Animal Care and Use Committee of the Medical College of Wisconsin. Epac1 knock-out mice $\left(\right.$ Epac1 $\left.^{-/-}\right)$, Epac2 knock-out mice $\left(E p a c 2^{-1-}\right)$, and Epac1 and 2 double knock-out mice $\left(\mathrm{Epac}^{-/-}\right)$were generated and maintained on a 129Sv background in the laboratory of Youming Lu as detailed previously (Yang et al., 2012). $\mathrm{Epac1}^{-/-}$or Epac2 ${ }^{-1-}$ mice were bred to $129 \mathrm{~Sv}$ wild-type mice at the Medical College of Wisconsin for at least two generations to generate heterozygous Epac1 ${ }^{+/-}$or Epac2 ${ }^{+/-}$breeders. Wild-type $\left(\mathrm{Epac}^{+/+}\right)$, $\mathrm{Epac1}^{-1-}$, or $\mathrm{Epac2}^{-1-}$ knock-out mice were generated by heterozygous $\times$ heterozygous breeding, and all experiments were performed in age-matched littermates of either sex. Epac double knock-out $\left(\right.$ Epac $\left.^{-/-}\right)$ mice were generated by crossing Epac1 ${ }^{-/-}$with Epac2 ${ }^{-/-}$mice. Genotyping analysis was performed by using a standard PCR technique on ear or tail biopsies.

Brain slice preparation. Epac1 $1^{-/-}, \mathrm{Epac}^{-/-}$, and $\mathrm{Epac}^{-/-}$mice and their wild-type littermates $\left(\mathrm{Epac}^{+/+} ; \mathrm{P} 20-\mathrm{P} 24\right)$ of either sex were used for slice electrophysiology. In some experiments, the mice were given a single intraperitoneal injection of either saline $(0.9 \% \mathrm{NaCl}, 2 \mathrm{ml} / \mathrm{kg})$ or cocaine $(15 \mathrm{mg} / \mathrm{kg})$. In experiments described in Figure 8 , adult Epac2 ${ }^{-/-}$mice and wild-type littermates (9-10 weeks old at the beginning of the experiments) underwent place conditioning and behavioral tests (see below, CPP). Twenty-four hours after the injections or behavioral tests, mice were anesthetized by isoflurane inhalation and decapitated. Midbrain slices (200 $\mu \mathrm{m}$ thickness) were cut using a Leica vibrating slicer VT1200s. Slices were prepared in choline-based solution containing the following (in mM): 110 choline chloride, $2.5 \mathrm{KCl}, 1.25 \mathrm{NaH}_{2} \mathrm{PO}_{4}$, $0.5 \mathrm{CaCl}_{2}, 7 \mathrm{MgSO}_{4}, 26 \mathrm{NaHCO}_{3}, 25$ glucose, 11.6 sodium ascorbate, and 3.1 sodium pyruvate. Slices were transferred immediately into the artificial CSF (ACSF; in mM): $119 \mathrm{NaCl}, 2.5 \mathrm{KCl}, 2.5 \mathrm{CaCl}_{2}, 1 \mathrm{MgCl}_{2}, 1.25$ $\mathrm{NaH}_{2} \mathrm{PO}_{4}, 26 \mathrm{NaHCO}_{3}$, and 10 glucose. All solutions were saturated with $95 \% \mathrm{O}_{2}$ and $5 \% \mathrm{CO}_{2}$. Slices were allowed to recover at least $1 \mathrm{~h}$ before recording.

Electrophysiology. Whole-cell patch-clamp recordings were made using patch-clamp amplifiers (Multiclamp 700B) under infrared differential interference contrast (DIC) microscopy. Data acquisition and analysis were performed using a DigiData 1440A digitizer and the analysis software pClamp 10 (Molecular Devices). Signals were filtered at 2 $\mathrm{kHz}$ and sampled at $10 \mathrm{kHz}$. Dopamine neurons in the VTA were identified by long-duration ( $>1.5 \mathrm{~ms}$ ) spontaneous action potentials in cellattached configuration (Chieng et al., 2011) and the presence of large $I_{\mathrm{h}}$ currents (Johnson and North, 1992). For recording of evoked EPSCs, electrical stimulation was delivered by a bipolar tungsten stimulation electrode (WPI) that was placed at fixed distance $(\sim 150 \mu \mathrm{m})$ rostral to the soma of the recorded dopamine neuron. Unless indicated otherwise, the stimulation strength was set to $30-40 \mu \mathrm{A}$, which yielded EPSCs of $20-30 \%$ maximum amplitude. For comparing the paired-pulse ratio (PPR), input/output (I/O) relationship, and miniature EPSCs (mEPSCs) in Figure 3, experiments were performed blind to genotypes of the mice. The $\mathrm{GABA}_{\mathrm{A}}$ receptor blocker picrotoxin $(100 \mu \mathrm{M})$ was included in the ACSF. mEPSCs were recorded in the presence of tetrodotoxin $(0.5 \mu \mathrm{M})$ to block action potential firing. For the I/O curves in Figure $3 E$, we applied incremental stimulation intensities (from 10 to $90 \mu \mathrm{A}$ in a step of $10 \mu \mathrm{A}$ ). The PPR was measured by the amplitude of EPSCs of the second pulse in relation to the first pulse $(20,40,100,200$, and $400 \mathrm{~ms}$ interpulse intervals).

Glass pipettes (3-5 $\mathrm{M} \Omega$ ) were filled with an internal solution containing the following (in mM): $130 \mathrm{Cs}$-methanesulfonate, $10 \mathrm{CsCl}, 10 \mathrm{HEPES}$, 1.1 EGTA, $2 \mathrm{MgCl}_{2}$, 4 MgATP, $0.3 \mathrm{Na}_{2} \mathrm{GTP}, 10 \mathrm{Na}_{2}$-phosphocreatine, and 0.1 spermine, $\mathrm{pH} 7.2$ with $\mathrm{CsOH}$. For the measurement of the current-voltage $(I-V)$ relationship and the rectification index $(\mathrm{RI})$, the NMDAR antagonist D-(-)-2-amino-5-phosphonopentanoic acid (DAP-5; $50 \mu \mathrm{M}$ ) was present in the ACSF. The AMPAR/NMDAR ratio was 
measured based on previously published studies (Saal et al., 2003; Liu et al., 2005). Neurons were voltage clamped at $40 \mathrm{mV}$ to record dualcomponent EPSCs containing both AMPAR- and NMDAR-EPSCs that were isolated pharmacologically. After a stable baseline recording of total EPSCs, the NMDAR antagonist D-AP-5 (50 $\mu \mathrm{M})$ was applied in the bath for 6-10 min to isolate fast AMPAR-EPSCs. NMDAR-EPSCs were calculated as the subtraction of AMPAR-EPSCs from the total EPSCs from the same neuron. An average of 10-20 consecutive EPSCs was collected for the each type of EPSCs. The AMPAR/NMDAR ratio was calculated by dividing the peak of the AMPAR-EPSCs by the peak of the NMDAREPSCs. Series resistance (15-20 M $\Omega$ ) was monitored throughout all recordings, and data were discarded if the resistance changed by $>20 \%$. All recordings were performed at $32 \pm 1^{\circ} \mathrm{C}$ by using an automatic temperature controller (Warner Instruments).

Animal surgery and intra-VTA microinjections of adeno-associated virus. The Epac2-shRNA (corresponding to nucleotides 1236-1257) and scramble-shRNA (Woolfrey et al., 2009) were packed into adenoassociated virus 2 (AAV2) with an EGFP reporter at the University of Pennsylvania Viral Vector Core. Adult wild-type mice (8-10 weeks old) were anesthetized with ketamine $(90 \mathrm{mg} / \mathrm{kg}$, i.p.) and xylazine $(10 \mathrm{mg} / \mathrm{kg}$, i.p.) and placed in a stereotaxic device (David Kopf Instruments). Recombinant AAV carrying AAV2.U6.ShR.Epac2.CMV.EGFP.SV40 or AAV2.U6.ShR.scramble.CMV.EGFP.SV40 (0.3 $\mu \mathrm{l} /$ side $)$ was microinjected bilaterally into the VTA via injector cannulae (33 gauge; Plastics One), which were connected through C313C connectors to $2 \mu$ l Hamilton microsyringes. The stereotaxic coordinates for VTA were as follows: anteroposterior, $-3.1 \mathrm{~mm}$; mediolateral, $\pm 1.0 \mathrm{~mm}$; dorsoventral, -4.8 $\mathrm{mm}$ at a $7^{\circ}$ angle (Paxinos and Franklin, 2001). The injection rate was 0.3 $\mu$ lover $5 \mathrm{~min}$, and the injectors were kept in place for an additional $5 \mathrm{~min}$ to ensure adequate AAV diffusion from the injector tip. After the surgery, animals received subcutaneous injections of analgesic (buprenorphine, $0.05 \mathrm{mg} / \mathrm{kg}$ ) three times daily for 2 days. Mice were allowed to recover for 3 weeks before behavioral experiments (see below).

$C P P$. Cocaine CPP was based on published procedures (Vialou et al., 2012). Epac ${ }^{+/+}, \mathrm{Epac1}^{-/-}, \mathrm{Epac}^{-/-}$, and Epac ${ }^{-/-}$mice (2-3 months old) of either sex were placed into the middle chamber of the threechamber conditioning apparatus (Med Associates) and allowed to explore three chambers freely for $20 \mathrm{~min}$, and time spent in every chamber was recorded. Mice showing unconditioned side preference ( $\geq 180 \mathrm{~s}$ disparity) were excluded. On days 2 and 3, mice were injected with saline $(0.9 \% \mathrm{NaCl}, 2 \mathrm{ml} / \mathrm{kg}$, i.p.) in the morning (between 8:00 A.M. and 10:00 A.M.) and confined to one chamber for $30 \mathrm{~min}$, and then the mice were injected with cocaine $(15 \mathrm{mg} / \mathrm{kg}$, i.p.) in the afternoon (between 3:00 P.M. and 5:00 P.M.) and confined for $30 \mathrm{~min}$ to the other chamber. On day 4, mice were tested for side preference without treatment for $20 \mathrm{~min}$ (between 12:00 P.M. and 2:00 P.M.).

Immunohistochemistry. Mice were anesthetized by ketamine $(90 \mathrm{mg} /$ $\mathrm{kg}$, i.p.) and xylazine (10 mg/kg, i.p.) and perfused transcardially with $0.1 \mathrm{~m}$ sodium PBS, followed by $4 \%$ paraformaldehyde in $4 \%$ sucrose$\mathrm{PBS}, \mathrm{pH}$ 7.4. After perfusion, the brain was removed, postfixed in the same fixative for $4 \mathrm{~h}$ at $4^{\circ} \mathrm{C}$, dehydrated in increasing concentrations of sucrose $(20 \%$ and $30 \%)$ in $0.1 \mathrm{M} \mathrm{PBS}$ at $4^{\circ} \mathrm{C}$, and frozen on dry ice. Coronal VTA sections $(20 \mu \mathrm{m})$ were cut with a Leica cryostat. VTA sections were incubated with antibodies against tyrosine hydroxylase (TH; rabbit, 1:300; Santa Cruz Biotechnology) at $4^{\circ} \mathrm{C}$ for $24 \mathrm{~h}$. VTA sections were then incubated in anti-rabbit IgG-Texas Red conjugate (1:200; Santa Cruz Biotechnology) for $4 \mathrm{~h}$ at room temperature in the dark. Confocal imaging was performed using a Nikon TE2000-U inverted microscope equipped with the $\mathrm{C} 1 \mathrm{Plus}$ confocal system (laser light source for EGFP excitation, $488 \mathrm{~nm}$, C-FL B-2E/C FITC filter cube; laser light source for Texas Red excitation, $561 \mathrm{~nm}, \mathrm{C}-\mathrm{FL}$ Y-2E/C Texas filter cube). The images were acquired using $10 \times \mathrm{CFI}$ Plan $10 \times$ Apochromat Objective (numerical aperture 0.45 ) or CFI plan Fluor $40 \times$ oilimmersion objective (numerical aperture 1.4), Nikon D-Eclipse C1 camera, and EZ-C1 software.

Statistics. Data are presented as the mean \pm SEM. CPP scores were calculated as the time spent in the cocaine-conditioned chamber minus that in the saline-conditioned chamber (Zhong et al., 2012; Yu et al., 2013). The RI was calculated by the current ratio of EPSCs between -70 and $+40 \mathrm{mV}\left(\mathrm{RI}=\right.$ EPSCs $_{-70 \mathrm{mV}} /$ EPSCs $\left._{+40 \mathrm{mV}}\right)$. Datasets were compared with Student's $t$ test or one-way or two-way ANOVA, followed by Tukey's post hoc analysis. Post hoc analyses were performed only when the ANOVA yielded a significant main effect or a significant interaction between the two factors. When there was no significant interaction, we made planned comparisons to test a priori hypotheses and to determine whether the two specific groups were significantly different. For statistical analysis of locomotor activity in CPP chambers, a mixed-design ANOVA with the between-subjects factors of place conditioning and genotypes and repeated measures on the conditioning sessions was used. Results were considered to be significant at $p<0.05$.

Chemicals. Picrotoxin, spermine and all other common chemicals were obtained from Sigma-Aldrich. D-AP5, 8-CPT-2Me-cAMP sodium salt, 1-Naphthyl acetyl spermine trihydrochloride (Naspm) trihydrochloride, 6-Bnz-cAMP sodium salt, H89 dihydrochloride, Pep2-EVKI, Pep2-SVKE, SKF86002 dihydrochloride, and SB203580 hydrochloride were obtained from Tocris Bioscience. Cocaine $\mathrm{HCl}$ was provided by the National Institute on Drug Abuse Drug Supply Program.

\section{Results}

\section{Epac2 is required for the cocaine-induced change in AMPAR subunit composition}

GluA2-containing AMPAR-mediated EPSCs show a linear $I-V$ relationship and are insensitive to polyamine channel blockers, such as Naspm. In contrast, GluA2-lacking AMPAR-mediated EPSCs show an inwardly rectifying $I-V$ curve and are sensitive to blockade by Naspm (Isaac et al., 2007). The insertion, removal, and replacement of synaptic GluA2-lacking AMPARs, but not GluA2-containing AMPARs, will alter the RI (see Materials and Methods) and the sensitivity of EPSCs to polyamine channel blockers (Bellone and Lüscher, 2006; Isaac et al., 2007). A single cocaine injection to mice increases the RI and renders EPSCs sensitive to polyamine blockade in VTA dopamine neurons, suggesting that cocaine exposure causes an increase in GluA2lacking AMPARs (Bellone and Lüscher, 2006; Argilli et al., 2008; Mameli et al., 2009; Brown et al., 2010; Good and Lupica, 2010). We examined whether the cocaine-induced change in AMPAR subunit composition in the VTA was altered by genetic deletion of Epac. During early development (P12-P16), there was a switch from the expression of GluA2-lacking AMPARs into GluA2containing AMPARs in principle neocortical neurons (for review, see Bellone and Lüscher, 2012). GluA2-lacking AMPARs are expressed in mouse VTA dopamine neurons during the early postnatal period (P2-P6) but are replaced with GluA2containing AMPARs earlier than P14 (Bellone et al., 2011). In the present study, all electrophysiology experiments were performed in P20-P24 mice or adult mice (Fig. 8 only; see Materials and Methods).

$\mathrm{Epac}^{+{ }^{+}}$and $\mathrm{Epac}^{-/-}$mice (P20-P24) were given a single saline or cocaine injection, and midbrain slices were prepared $24 \mathrm{~h}$ later. Whole-cell recordings were made from VTA dopamine neurons while EPSCs were recorded at various holding potentials $(-70,-40,-20,0,+20$, and $+40 \mathrm{mV})$. Two-way ANOVA showed that cocaine treatment and genotype had significant effects on the RI (cocaine, $F_{(1,36)}=8.9, p=0.005$; genotype, $\left.F_{(1,36)}=6.6, p=0.015\right)$; there was a significant interaction between cocaine treatment and genotype $\left(F_{(1,36)}=5.9, p=0.021\right.$; Fig. 1). Tukey's post hoc tests indicated that cocaine treatment significantly increased the RI in Epac ${ }^{+/+}$slices $(p<0.001$; Fig. $1 A, C)$ but had no significant effect on the RI in $E_{p a c}{ }^{-/}$slices $(p=0.706$; Fig. $1 B, C)$.

We determined whether the selective GluA2-lacking AMPARs blocker Naspm (Tsubokawa et al., 1995) affected EPSCs in midbrain slices prepared from Epac ${ }^{+/+}$and $\mathrm{Epac}^{-1-}$ mice that had 
A $\mathrm{Epac}^{+/+}$
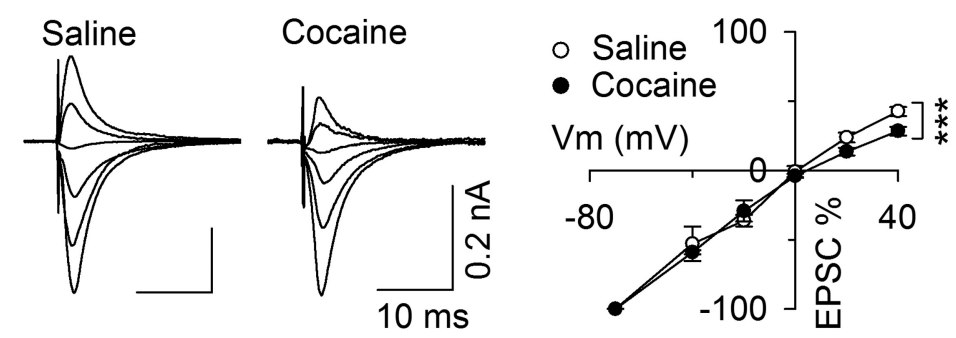

B

$\mathrm{Epac}^{-1-}$
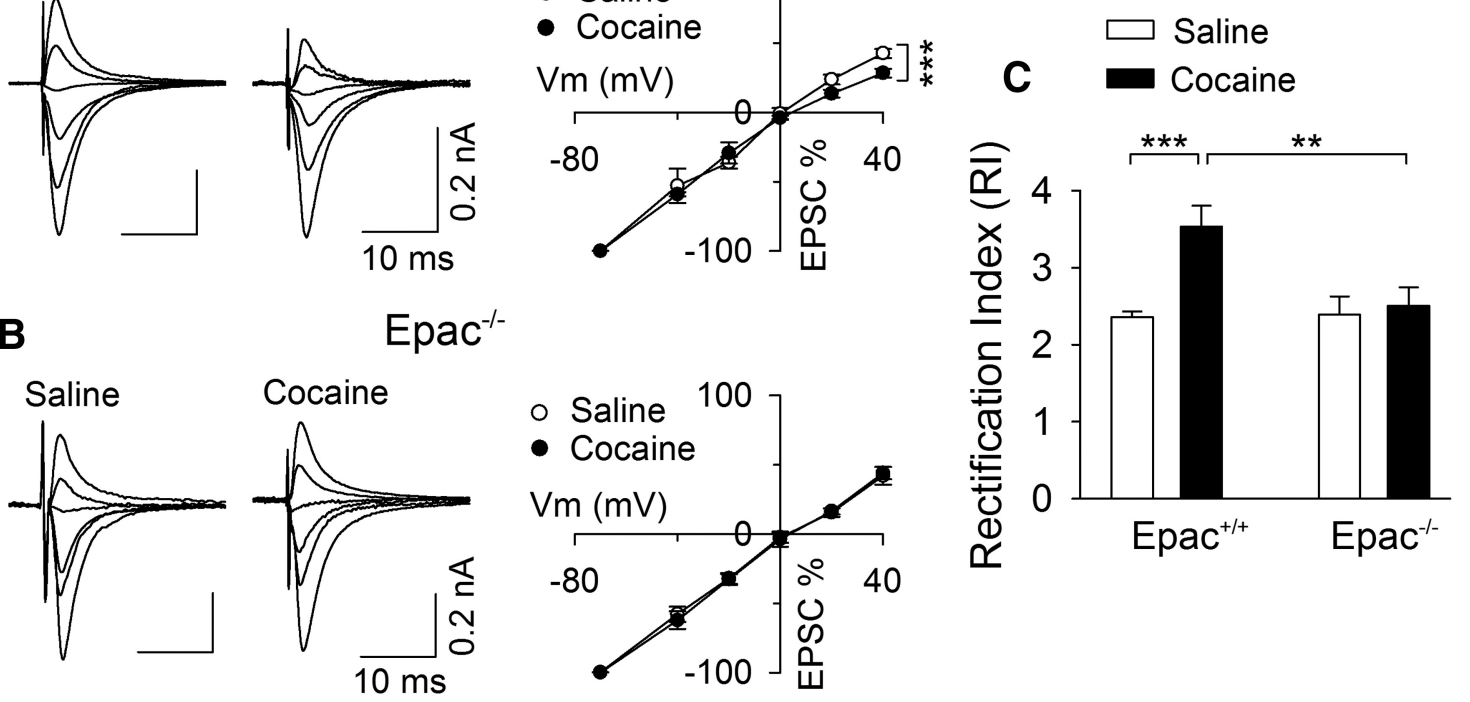

Figure 1. Genetic deletion of Epac blocked the increase in the Rl induced by in vivo cocaine exposure. $A$, In wild-type $\left(E p a C^{+/+}\right)$mice, a single cocaine injection in vivo caused inward rectification of AMPAR-mediated EPSCs in VTA dopamine neurons ex vivo. AMPAR-EPSCs at $+40,+20,0,-20,-40$, and $-70 \mathrm{mV}$ were normalized to those of $-70 \mathrm{mV}$ to generate $l--V$ curves $(n=10$ for each group). $\boldsymbol{B}$, In Epac double knock-out (Epac ${ }^{-1-}$ ) mice, a single cocaine injection in vivo did not significantly alter the $I-V$ relationship of EPSCs $(n=8-9)$. $C$, A single cocaine injection in vivo significantly increased the Rl in Epac ${ }^{+/+}$slices $\left({ }^{* * *} p<0.001 ; n=10\right)$ but not in Epac ${ }^{-/-}$slices $(p=0.706 ; n=8-9)$. Cocaine-induced increase in the Rl was blocked in Epac ${ }^{-/-}$mice ${ }^{* *} p=$ $0.002 ; n=8-10)$.
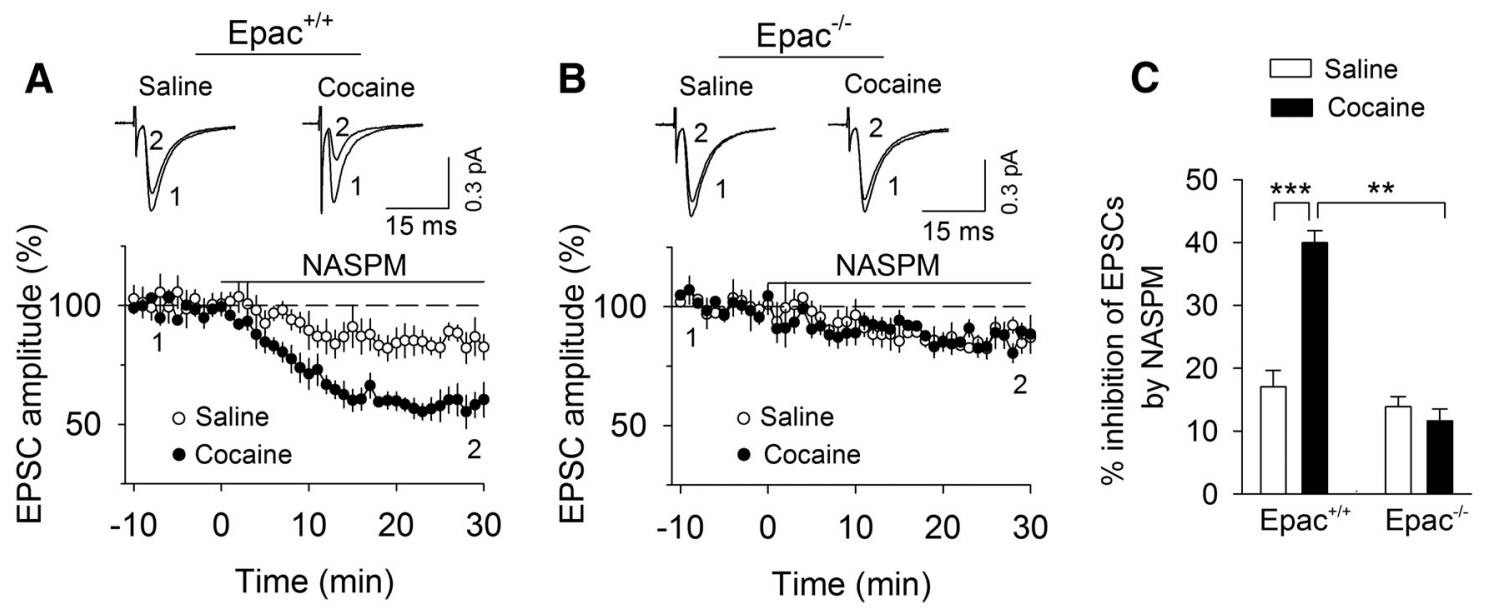

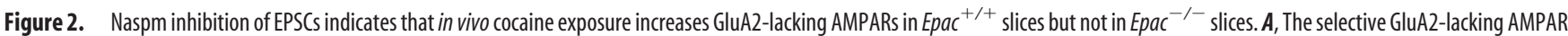
blocker Naspm induced greater depression of EPSCs in slices from $\mathrm{Epac}^{+/+}$mice that received a single cocaine injection compared with those received a single saline injection $(* * * p<0.001$; $n=8$ for each group). $\boldsymbol{B}$, Epac knock-out abrogated the effect of in vivo cocaine injection on Naspm inhibition of EPSCS $(p=0.432 ; n=8-9)$. C, Summarized data showed the effects of NASPM on EPSCs in these four groups $\left({ }^{* *} p=0.001, n=8-8 ;{ }^{* * *} p<0.001, n=8-8\right.$ ).

received saline or cocaine injection. Bath application of Naspm $(100 \mu \mathrm{M})$ caused significantly greater depression of EPSCs in slices from $\mathrm{Epac}^{+/+}$mice that received cocaine injection than those that received saline injection ( $p<0.001$; Fig. $2 A, C)$. Naspm did not significantly affect EPSCs in Epac ${ }^{-/-}$mice that received saline or cocaine injection $(p=0.432$; Fig. $2 B, C)$. Together, the increases in the RI and sensitivity to Naspm suggest that a single cocaine injection in vivo causes an increase in GluA2lacking AMPARs in $\mathrm{Epac}^{+/+}$mice but not in $\mathrm{Epac}^{-/-}$mice.

We next examined whether Epac knock-out altered basal AMPAR-mediated EPSCs in VTA dopamine neurons. mEPSCs were generated by action potential-independent, quantal glutamate release from presynaptic axonal terminals (Zhu and
Lovinger, 2005). We recorded mEPSCs in VTA dopamine neurons in midbrain slices prepared from $\mathrm{Epac}^{+/+}$and $\mathrm{Epac}^{-/-}$ mice. There was no significant difference in the frequency $\left(t_{(19)}=\right.$ $0.7, p=0.516)$ or amplitude $\left(t_{(19)}=0.6, p=0.573\right)$ of mEPSCs between $\mathrm{Epac}^{+/+}$and Epac ${ }^{-/-}$slices (Fig. 3A-C). We also measured the PPR of evoked EPSCs at interpulse intervals of 20-400 $\mathrm{ms}$. The change in the PPR suggests a change in presynaptic release probability (Zucker and Regehr, 2002). The PPR was not significantly different at all intervals tested between $\mathrm{Epac}^{+/+}$and Epac $^{-/-}$slices $\left(20 \mathrm{~ms}, t_{(14)}=0.5, p=0.637 ; 50 \mathrm{~ms}, t_{(14)}=0.8\right.$, $p=0.442 ; 100 \mathrm{~ms}, t_{(14)}=0.3, p=0.756 ; 200 \mathrm{~ms}, t_{14}=1.1, p=$ $0.285 ; 400 \mathrm{~ms}, t_{(14)}=1.5, p=0.152$; Fig. $\left.3 D\right)$. Finally, we measured I/O relationships of EPSCs in response to stimuli with 
A

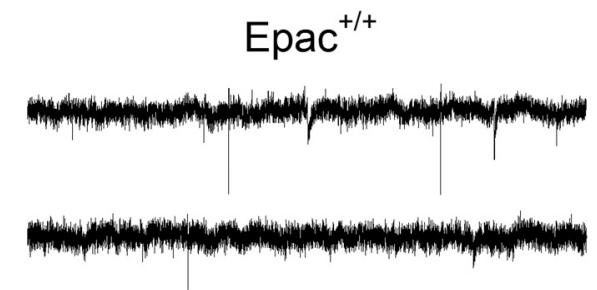

B

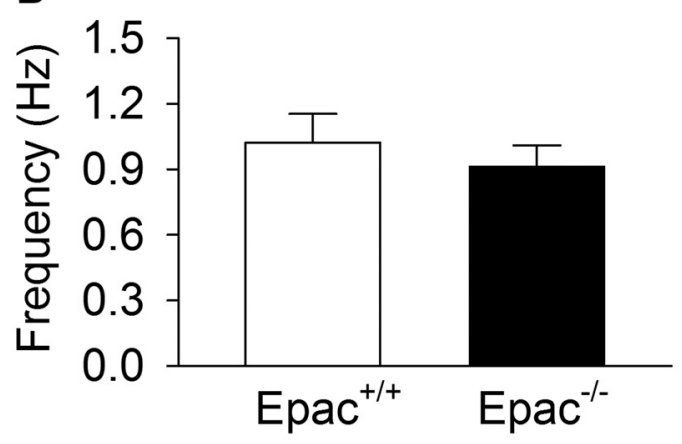

D
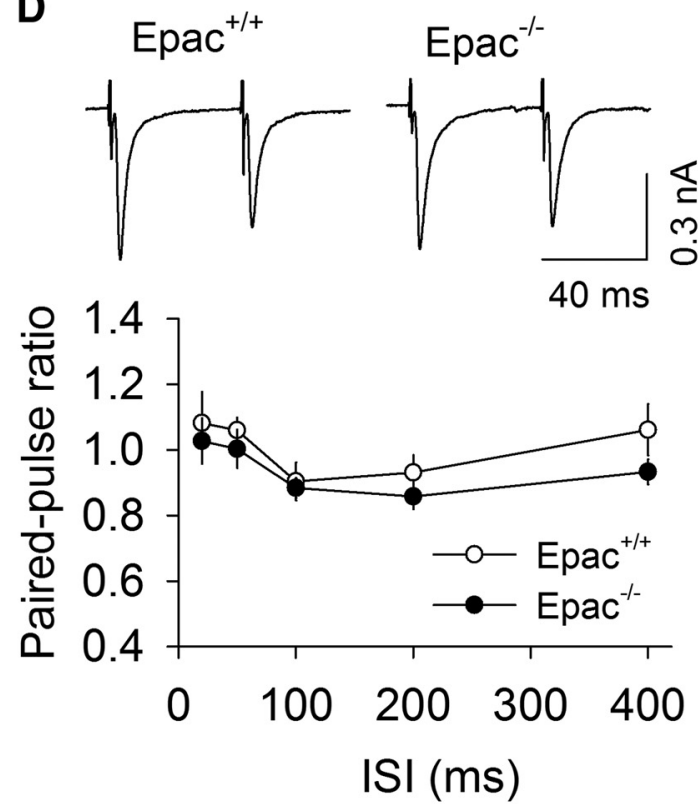

$\mathrm{Epac}^{-1-}$

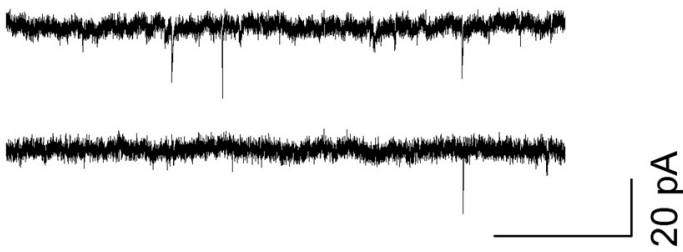

$0.5 \mathrm{~s}$

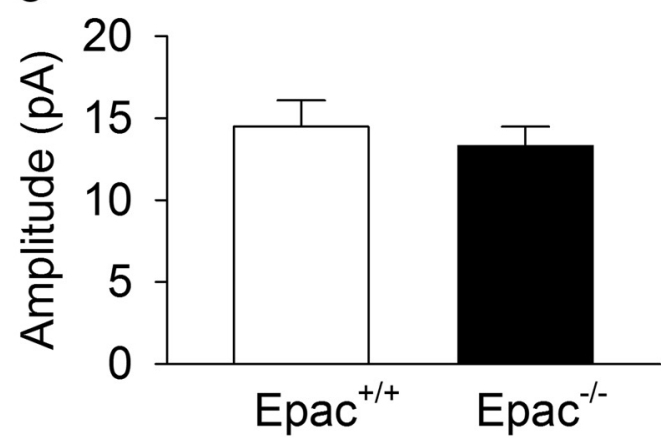

E
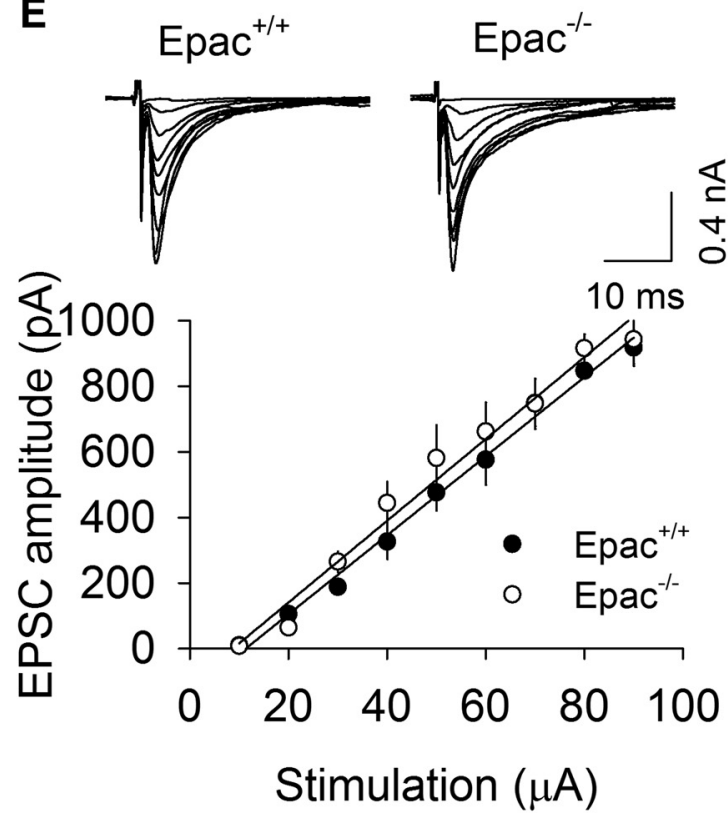

Figure 3. Epac knock-out did not significantly alter basal AMPAR-mediated EPSCs in VTA dopamine neurons. A, Sample mEPSCs recorded from VTA dopamine neurons in Epac ${ }^{+/+}$slices and Epac $^{-1-}$ slices. $\boldsymbol{B}, \boldsymbol{C}$, Epac knock-out had no significant effects on the frequency $(p=0.516 ; n=9-11)$ and amplitude $(p=0.573 ; n=9-11)$ of mEPSCS. $\boldsymbol{D}$, The PPR was not significantly different at all intervals $(20-400 \mathrm{~ms})$ tested between Epac ${ }^{+/+}$and Eac $^{-/-}$slices $(p>0.05 ; n=7-8)$. E, Epac knock-out $\left(\right.$ Epac $\left.^{-/-}\right)$did not significantly alter the slope of I/0 curves compared with wild-type Epac $^{+/+}$slices $(p=0.660 ; n=8-10)$.

incremental intensities. There was no significant difference of the slope of I/O curves between $\mathrm{Epac}^{+/+}$and $\mathrm{Epac}^{-/-}$slices $\left(t_{(17)}=0.5, p=0.660\right.$; Fig. $\left.3 E\right)$. Together, these results indicate that genetic deletion of Epac did not significantly alter basal AMPAR-mediated synaptic transmission in VTA dopamine neurons.

Although Epac2 is the predominant isoform expressed in the brain (Kawasaki et al., 1998; de Rooij et al., 1998; Ostroveanu et al., 2010), recent studies indicate functional redundancy of the two isoforms (Yang et al., 2012). We next determined whether in vivo cocaine injection altered the RI in Epac1 ${ }^{-1-}$ and $\mathrm{Epac2}^{-1-}$ mice. Epac1 ${ }^{-/-}$and $E p a c 2^{-/-}$mice received a single saline or cocaine injection, and midbrain slices were prepared $24 \mathrm{~h}$ later. A two-way ANOVA showed that cocaine treatment $\left(F_{(1,32)}=11.4\right.$, $p=0.002)$ and genotype $\left(F_{(1,32)}=7.2, p=0.012\right)$ had significant effects on the RI, and there was a significant interaction between cocaine treatment and genotype $\left(F_{(1,32)}=11.1, p=0.002\right.$; Fig. 4$)$. Tukey's post hoc tests indicated that cocaine treatment significantly increased the RI in $E_{p a c 1}{ }^{-1-}$ slices ( $p<0.001$; Fig. 4A,C) but had no significant effect on the RI in Epac2 ${ }^{-1-}$ slices ( $p=$ 0.983; Fig. 4 B, C). Thus, Epac2, but not Epac1, is required for the change in AMPAR subunit composition induced by a single cocaine injection in vivo. 
A

Epac1-/-

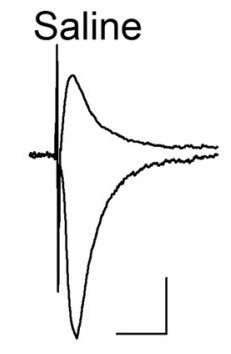

B

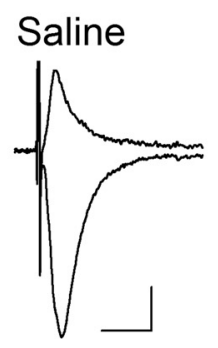

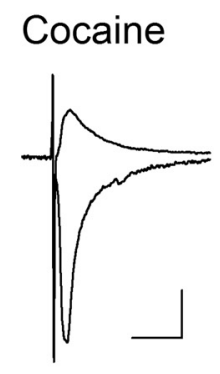

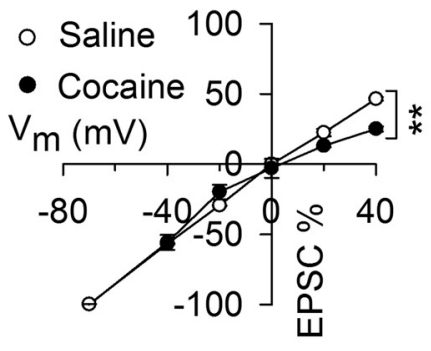

\section{Epac2-/-}

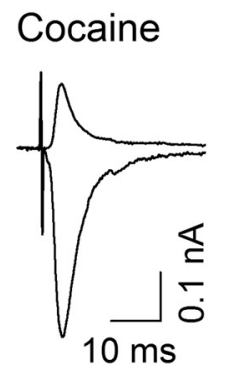

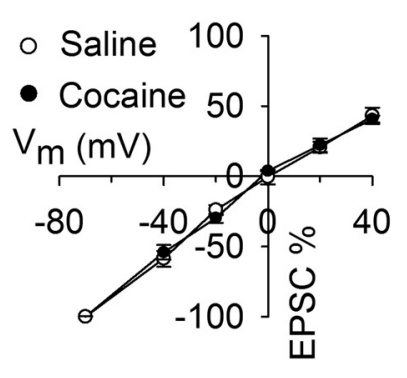
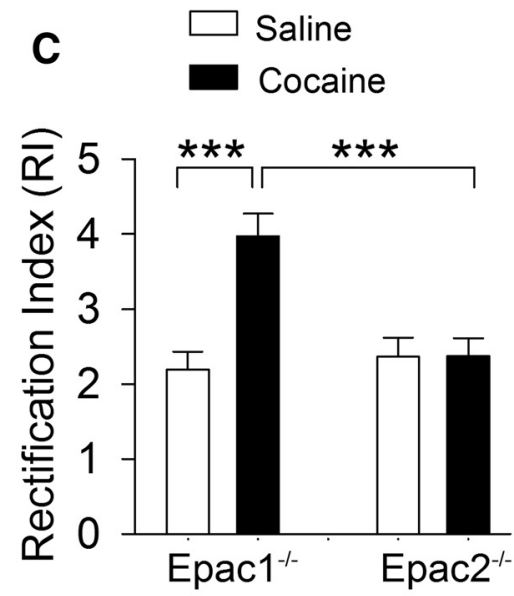

Figure 4. Epac2 but not Epac1 is required for the increase in the RI induced by a single cocaine injection in vivo. $\boldsymbol{A}$, In Epac $1^{-/-}$mice, a single cocaine injection in vivo caused inward rectification of AMPAR-mediated EPSCs in VTA dopamine neurons ex vivo. AMPAR-EPSCs at +40 and $-70 \mathrm{mV}$ were normalized to those of $-70 \mathrm{mV}$ to generate $/--V$ curves $(n=8-9)$. $\boldsymbol{B}$, In Epac $2^{-/-}$mice, a single cocaine injection in vivo did not significantly alter the $I-V$ relationship of EPSCs $(n=7-9)$. C, A single cocaine injection in vivo significantly increase the RI in Epac ${ }^{-/-}$slices ${ }^{* * *} p<0.001$; $n=8-9)$ but not in Epac ${ }^{-/-}$slices $(p=0.983 ; n=7-9)$.

\section{The selective Epac agonist 8-CPT altered AMPAR subunit composition in the VTA}

Having shown that genetic deletion of Epac blocked the cocaineinduced increase in GluA2-lacking AMPARs, we next determined whether activation of Epac itself altered AMPAR subunit composition in the VTA. The cAMP analog 8-CPT is a selective Epac agonist (Enserink et al., 2002). 8-CPT-containing (100 $\mu \mathrm{M})$ or 8-CPT-free internal solution was dialyzed into VTA dopamine neurons in $\mathrm{Epac}^{+/+}$and Epac2 ${ }^{-/-}$slices for $10 \mathrm{~min}$ before EPSCs were recorded. The two-way ANOVA indicates that 8 -CPT $\left(F_{(1,34)}=7.0, p=0.013\right)$ and genotype $\left(F_{(1,34)}=8.4, p=0.007\right)$ had significant effects on the RI, and there was a significant interaction between 8-CPT and genotype $\left(F_{(1,34)}=5.0, p=0.033\right)$. Tukey's post hoc tests indicated that 8 -CPT increased the RI in Epac $^{+/+}$slices $(p=0.002$; Fig. $5 A)$ but had no significant effect on the RI in Epac2 ${ }^{-/-}$slices ( $p=0.767$; Fig. $5 A$ ). We next determined whether 8-CPT altered the sensitivity of EPSCs to Naspm in VTA slices prepared from $\mathrm{Epac}^{+/+}$mice. Bath application of Naspm $(100 \mu \mathrm{M})$ caused greater attenuation of EPSCs in 8-CPTdialyzed neurons compared with that in time-matched control neurons $\left(t_{(14)}=6.3, p<0.001\right.$; Fig. $\left.5 B\right)$. Thus, 8 -CPT caused an increase in GluA2-lacking AMPARs in VTA dopamine neurons. These results suggest that activation of Epac2 by 8 -CPT mimics the effect of a single cocaine exposure in vivo in altering AMPAR subunit composition.

Binding of cAMP to Epac (but not PKA) activates Rap1 and Rap2, which are members of the Ras superfamily small GTPases that cycle between an inactive GDP-bound form and an active GTP-bound form (Kawasaki et al., 1998; de Rooij et al., 1998). Epac proteins catalyze the exchange of GDP for GTP and thereby activate Rap1 and Rap2 (Kawasaki et al., 1998; de Rooij et al., 1998). Rap can activate p38 mitogen-activated protein kinase (MAPK) to regulate GluA2 AMPAR trafficking (Zhu et al., 2002;
Ster et al., 2009). To test the possibility that 8-CPT increased the RI through p38, we examined whether the p38 inhibitors SB203580 and SKF86002 affected 8-CPT-induced changes in the RI in VTA dopamine neurons. Slices were perfused continuously with vehicle, SB203580 ( $2 \mu \mathrm{M})$, or SKF86002 (5 $\mu \mathrm{M})$. Whole-cell recordings were made with control internal solution or internal solution containing 8-CPT $(100 \mu \mathrm{M})$. A two-way ANOVA showed that 8 -CPT $\left(F_{(1,61)}=7.0, p=0.011\right)$ and the p38 inhibitors $\left(F_{(2,61)}=4.4, p=0.016\right)$ had significant effects on the RI, and there was a significant interaction between 8 -CPT and the p38 inhibitors $\left(F_{(2,61)}=6.3, p=0.004\right)$. Tukey's post hoc tests indicated that, in vehicle-treated slices, 8 -CPT significantly increased the RI ( $p<0.001$; Fig. $5 C)$. SB203580 or SKF86002 did not significantly alter the RI compared with the vehicle group (SB203580 vs vehicle, $p=0.806$; SKF86002 vs vehicle, $p=0.988$ ) but blocked the 8-CPT-induced increase in the RI (SB203580 vs vehicle, $p=0.002$; SKF86002 vs vehicle, $p<0.001$; Fig. $5 C$ ). Thus, it is likely that 8 -CPT altered the RI through activation of p38 MAPK.

We have shown above that 8 -CPT increased the RI and rendered EPSCs sensitive to blockade by Naspm (Fig. 5A,B), suggesting an increase in GluA2-lacking AMPARs in VTA dopamine neurons. Such an increase could be attributed to an insertion of GluA2-lacking AMPARs on top of existing AMPARs or, alternatively, the replacement of native GluA2-containing AMPARs with GluA2-lacking AMPARs (Bellone and Lüscher, 2006). The dominant-negative peptide Pep2-EVKI mimics the C-terminal sequence of the AMPAR subunit GluA2 and selectively disrupts the interaction of the subunit with protein interacting with $\mathrm{C}$ kinase (PICK1; Li et al., 1999). PICK1 regulates the removal and insertion of GluA2 AMPARs from and to the synapses (Gardner et al., 2005; Liu and Cull-Candy, 2005). We then examined whether Pep2-EVKI altered the RI in the VTA in Epac ${ }^{+/+}$slices. 
A
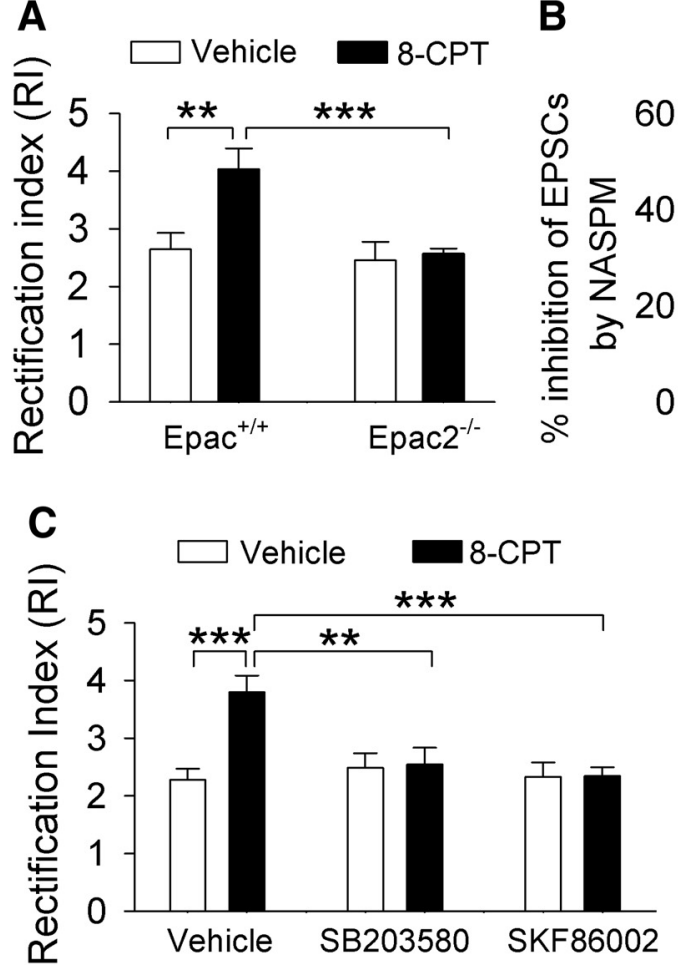

B

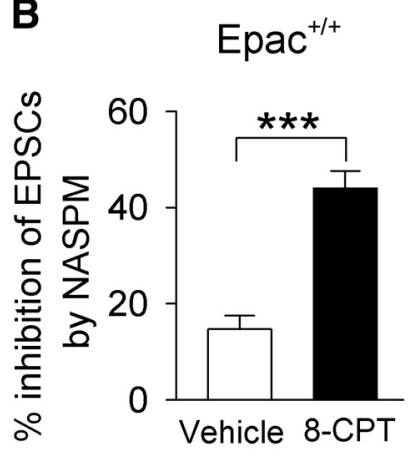

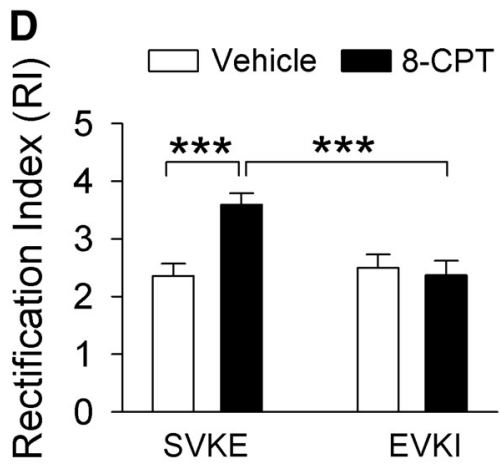

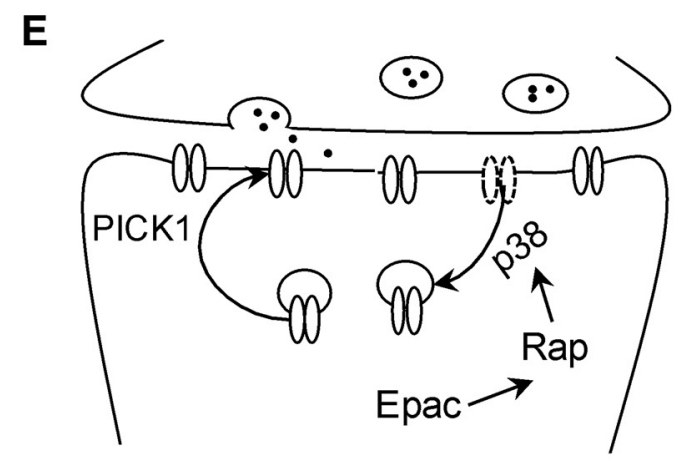

Figure 5. The selective Epac agonist 8-CPT increases GluA2-lacking AMPARs via activation of Epac2. A, Intracellular dialysis of 8-CPT increased the RI in VTA dopamine neurons in Epac ${ }^{+/+}$slices $\left({ }^{* *} p=0.002 ; n=7-10\right)$, which was blocked in Epac2 ${ }^{-/-}$slices $\left({ }^{* * *} p<0.001 ; n=8-10\right) . \boldsymbol{B}$, In Epac ${ }^{+/+}$slices, the selective GluA2-lacking AMPAR blocker Naspm (100 $\left.\mu \mathrm{M}\right)$ induced greater inhibition of EPSCs in 8-CPT-Ioaded neurons compared with that in control neurons $\left(^{* * *} p<0.001 ; n=7-8\right)$. C, Intracellular dialysis of 8-CPT (100 $\left.\mu \mathrm{m}\right)$ caused an increase in the Rl in Epac ${ }^{+/+}$slices $\left({ }^{* * *} p<0.001 ; n=11\right)$, which was blocked by the 38 inhibitor SB203580 $\left(2 \mu \mathrm{m}^{* * *} p=0.002 ; n=10-11\right)$ or SKF86002 $\left(5 \mu \mathrm{m} ;{ }^{* * *} p<0.001 ; n=10-11\right) . \boldsymbol{D}$, The PICK1 active peptide Pep2-EVKI $(100 \mu \mathrm{m})$ itself did not alter the RI $(p=0.649 ; n=8)$ but blocked the 8-CPT-induced increase in the RI (*** $p<0.001 ; n=7-8)$. E, A model shows how Epac activation leads to the change of AMPAR subunit composition.

Pep2-EVKI $(100 \mu \mathrm{M})$ or the inactive control peptide Pep2-SVKE $(100 \mu \mathrm{M})$ was dialyzed into VTA dopamine neurons with or without 8 -CPT $(100 \mu \mathrm{M})$ coapplication for at least 10 min before the RI was measured. A two-way ANOVA indicated that 8 -CPT $\left(F_{(1,30)}=6.4, p=0.018\right)$ and Pep2-EVKI $\left(F_{(1,30)}=6.1, p=\right.$ $0.020)$ had significant effects on the RI; there was a significant interaction between 8-CPT and Pep2-EVKI $\left(F_{(1,30)}=10.0, p=\right.$ $0.004)$. Tukey's post hoc tests indicated that Pep2-EVKI itself had no significant effect on the RI $(p=0.649)$ but blocked the 8 -CPT-induced increase in the RI $(p<0.001$; Fig. $5 D)$. Thus, the 8-CPT-induced change in AMPAR subunit composition required interaction of the GluA2 subunit with PICK1 that is known to regulate GluA2 trafficking at synapses (Bellone and Lüscher, 2006). Together, these results appeared to support a model in which Epac causes activation of the downstream effectors Rap1 and Rap2, which in turn activate p38 MAPK to remove GluA2 AMPARs from synapses. PICK1 is required for the removal and insertion of GluA2 AMPARs from and to the excitatory synapses onto VTA dopamine neurons (Fig. 5E).

\section{Epac2 knock-out impaired cocaine-induced increase in AMPAR/NMDAR ratio}

Single or repeated cocaine intraperitoneal injections lead to an increase in the AMPAR/NMDAR ratio in VTA dopamine neurons (Ungless et al., 2001; Borgland et al., 2004; Liu et al., 2005; Mameli et al., 2009). We examined whether the Epac2 knock-out altered cocaine-induced changes in the AMPAR/NMDAR ratio in VTA dopamine neurons. Epac ${ }^{+/+}$and Epac2 ${ }^{-/-}$mice received a single intraperitoneal injection of saline or cocaine $(15 \mathrm{mg} / \mathrm{kg})$. Midbrain slices were prepared from these four groups of mice
$24 \mathrm{~h}$ later. The AMPAR/NMDAR ratio in VTA dopamine neurons was measured as described previously (Zhong et al., 2015). The two-way ANOVA showed that cocaine $\left(F_{(1,31)}=10.2, p=\right.$ $0.003)$ and genotype $\left(F_{(1,31)}=18.4, p<0.001\right)$ had significant effects on the AMPAR/NMDAR ratio, and there was a significant interaction between cocaine treatment and genotype $\left(F_{(1,31)}=\right.$ 4.7, $p=0.039$; Fig. $6 A, B)$. Tukey's post hoc tests indicated that cocaine treatment significantly increased the AMPAR/NMDAR ratio in $\mathrm{Epac}^{+/+}$slices $(p<0.001)$ but not in Epac2 ${ }^{-/-}$slices $(p=0.144$; Fig. $6 A, B)$. Thus, Epac2 is required for the increase in the AMPAR/NMDAR ratio induced by a single cocaine injection in vivo.

We examined whether mEPSCs were altered in $\mathrm{Epac}^{+/+}$and Epac2 ${ }^{-/-}$mice that received a single cocaine injection. Two-way ANOVA showed that cocaine and genotype had significant effects on the frequency (cocaine, $F_{(1,39)}=7.9, p=0.008$; genotype, $\left.F_{(1,39)}=9.4, p=0.004\right)$ of and amplitude (cocaine, $F_{(1,39)}=4.4$, $p=0.043$; genotype, $\left.F_{(1,39)}=4.9, p=0.034\right)$ of mEPSCs, and there was significant interactions between cocaine treatment and genotype (frequency, $F_{(1,39)}=6.5, p=0.015$; amplitude, $F_{(1,39)}=$ $10.5, p=0.003)$. Tukey's post hoc tests indicated that cocaine treatment significantly increased the frequency and amplitude of mEPSCs in Epac ${ }^{+/+}$slices (both $p<0.001$ ) but not in Epac2 $2^{-/-}$ slices (frequency, $p=0.412$; amplitude, $p=0.855$; Fig. $6 C-E$ ). The increase in mEPSC amplitude would facilitate the detection of small mEPSCs that were previously below the threshold of detection, which might contribute to the increase in the frequency of mEPSCs. Our results suggest that a single cocaine injection in vivo led to an increase in AMPAR-mediated mEPSCs. 
A

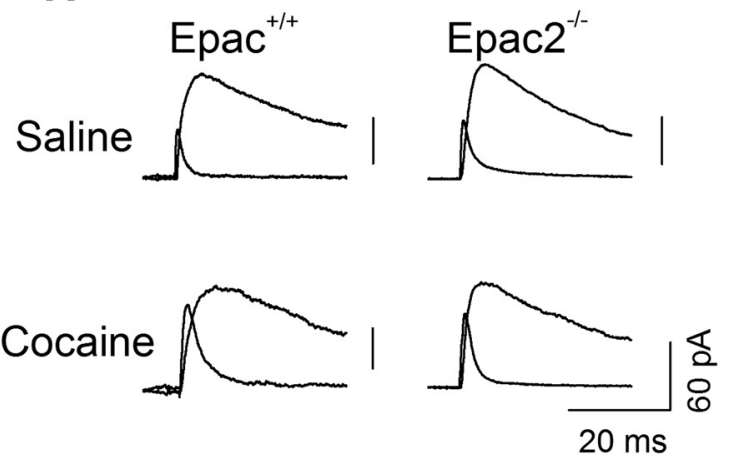

C

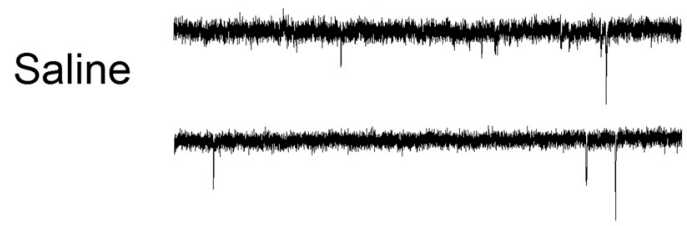

$\mathrm{Epac}^{+/+}$

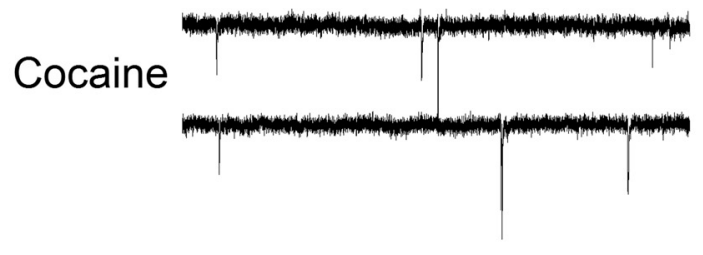

D

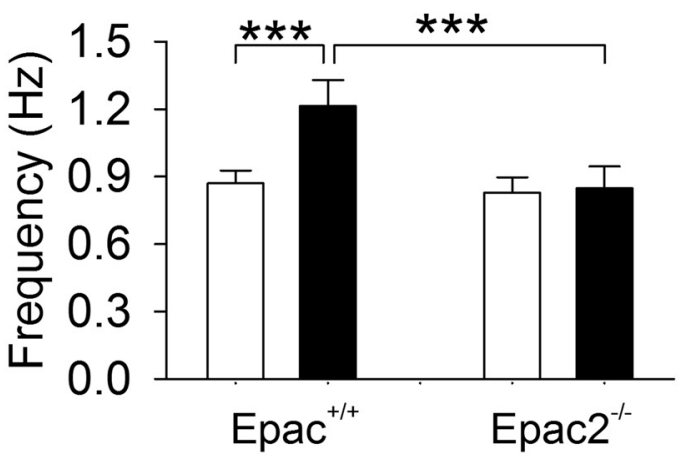

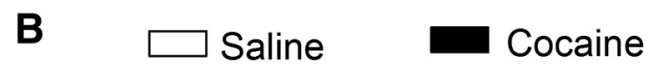

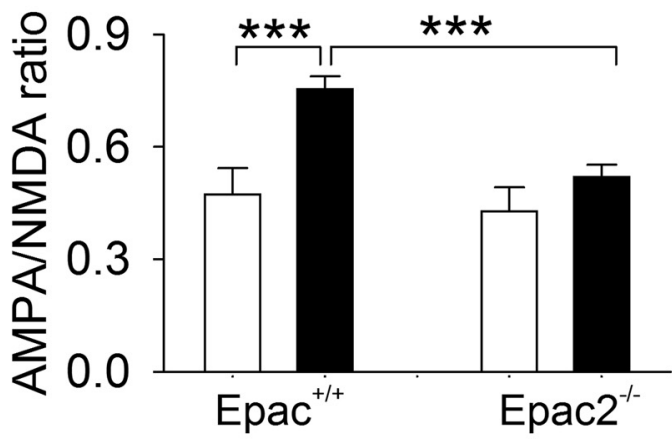

Epac2 $^{-1-}$
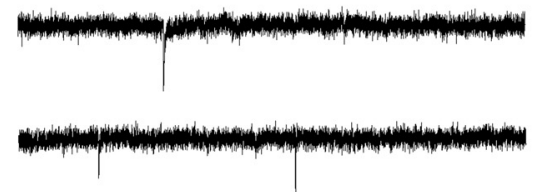

Epac2 $^{-1}$

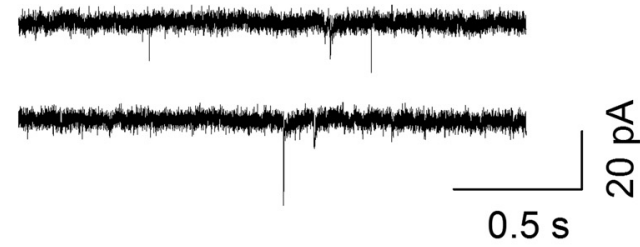

E

Saline

Cocaine

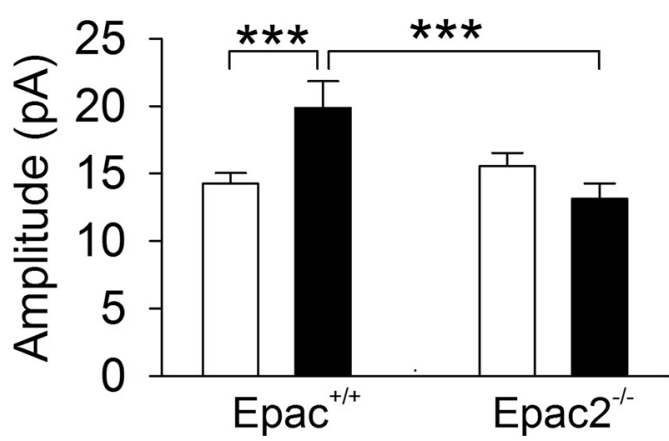

Figure 6. Genetic deletion of Epac2 blocked the increase in the AMPAR/NMDAR ratio induced by a single cocaine injection in vivo. Wild-type control and Epac2 ${ }^{-1-}$ mice received a single intraperitoneal injection of saline or cocaine $(15 \mathrm{mg} / \mathrm{kg})$. Midbrain slices were prepared from these four groups of mice the next day. $\boldsymbol{A}$, Representative AMPAR- and NMDAR-mediated evoked EPSCs recorded from VTA dopamine neurons. $\boldsymbol{B}$, A single cocaine injection in vivo significantly increased the AMPAR/NMDAR ratio in Epac ${ }^{+/+}$slices $\left({ }^{* * *} p<0.001 ; n=8\right.$ for each group), although this increase was blocked in Epac2 ${ }^{-/-}$slices ( ${ }^{* * *} p<0.001 ; n=8$ for each group). C, Representative mEPSCs recorded from VTA dopamine neurons in saline- or cocaine-treated Epac ${ }^{+/+}$and Epac $2^{-/-}$mice. $\boldsymbol{D}, \boldsymbol{E}$, A single cocaine injection in vivo significantly increased the frequency $\left({ }^{* * *} p<0.001\right)$ and amplitude $\left({ }^{* * *} p<0.001 ; n=9-10\right)$ of mEPSCs in Epac ${ }^{+/+}$slices, although these increases were blocked in Epac2 ${ }^{-/-}$slices (both ${ }^{* *} p<0.001 ; n=9-10$ ).

We determined whether acute activation of Epac or PKA altered the AMPAR/NMDAR ratio in VTA dopamine neurons. 6-Bnz-cAMP is a cAMP analog that selectively activates PKA but does not affect Epac (Hewer et al., 2011). Control, 8-CPT- (100 $\mu \mathrm{M})$, 6-Bnz-cAMP- $(100 \mu \mathrm{M})$, or 8-CPT plus 6-Bnz-cAMPcontaining internal solution was dialyzed into VTA dopamine neurons in $\mathrm{Epac}^{+/+}$slices for 10-15 min before the measurement of the AMPAR/NMDAR ratio. One-way ANOVA showed that intracellular dialysis of the different activators significantly changed the AMPAR/NMDAR ratio $\left(F_{(3,18)}=9.0, p<0.001\right)$. Tukey's post hoc tests indicated that 6-Bnz-cAMP alone $(p=$ $0.013)$ or 8 -CPT plus 6-Bnz-cAMP $(p=0.029)$ significantly increased the AMPAR/NMDAR ratio in $\mathrm{Epac}^{+/+}$slices, whereas 8 -CPT did not significantly change the AMPAR/NMDAR ratio $(p=0.916$; Fig. $7 A)$. We next examined whether intracellular dialysis of 8 -CPT or 6-Bnz-cAMP altered basal EPSCs in the 
A

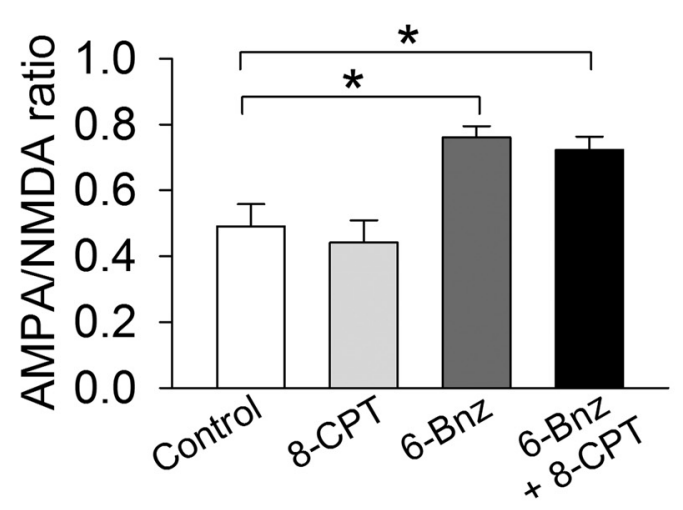

C

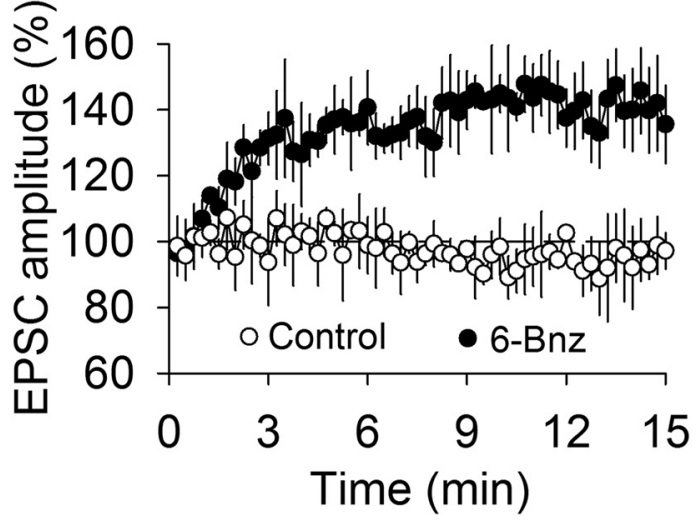

B

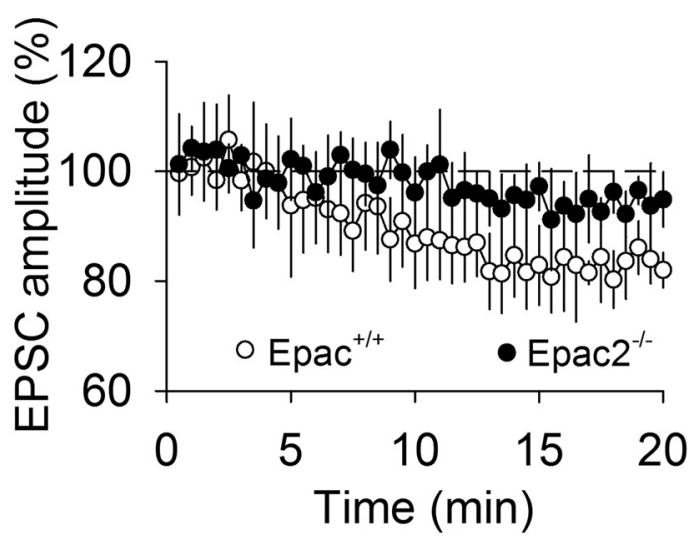

D

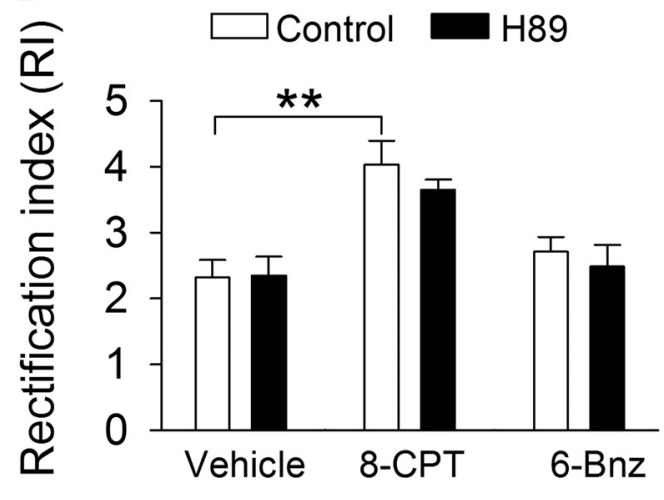

Figure 7. Effects of activation of Epac or PKA on the AMPAR/NMDAR ratio, basal AMPAR-EPSCs, and RI in VTA dopamine neurons. $A$, Intracellular dialysis of 6-Bnz-cAMP (6-Bnz; $100 \mu \mu$; * $p=$ $0.013 ; n=6)$ or $6-\mathrm{Bnz}+8-\mathrm{CPT}\left(100 \mu \mathrm{M} ;{ }^{*} p=0.029 ; n=7\right)$ significantly increased the AMPAR/NMDAR ratio in Epac ${ }^{+/+}$slices, whereas intracellular dialysis of 8-CPT did not significantly change the AMPAR/NMDAR ratio ( $p=0.916, n=6-7)$. B, Intracellular dialysis of 8-CPT caused a slow and graduate decrease in the amplitude of evoked EPSCs in Epac $+/+$ slices but did not significantly change EPSCs in Epac2 $2^{-/-}$slices $(p=0.049 ; n=9-10)$. C, Intracellular dialysis of 6-Bnz-CAMP caused rapid, robust enhancement of EPSCs in Epac ${ }^{+/+}$slices, whereas the control internal solution did not significantly change basal EPSCs $(p=0.007, n=10-11)$. D, 8 -CPT increased the RI $\left({ }^{* *} p=0.003 ; n=8-10\right)$. The PKA inhibitor H89 (10 $\left.\mu \mathrm{m}\right)$ did not alter the RI ( $\left.p=0.941 ; n=8-10\right)$, nor did it affect the 8-CPT-induced increase in the $\mathrm{RI}(p=0.347 ; n=10)$. 6-Bnz-cAMP did not alter the $\operatorname{RI}(p=0.276 ; n=8-9)$.

VTA. 8-CPT caused a gradual and modest decrease in the amplitude of evoked EPSCs in Epac ${ }^{+/+}$slices but did not significantly change EPSCs in Epac2 ${ }^{-/-}$slices (Fig. 7B). These results are mostly consistent with the finding that 8 -CPT induced long-term depression-like synaptic modification in the CA1 region of hippocampal slices (Ster et al., 2009). The modest change of AMPAR-EPSCs may explain why 8-CPT did not significantly change the AMPAR/NMDAR ratio. In contrast, intracellular dialysis of 6-Bnz-cAMP caused rapid, robust enhancement of EPSCs in $\mathrm{Epac}^{+/+}$slices, whereas control internal solution (drugfree) did not significantly change basal EPSCs (Fig. 7C). Thus, activation of PKA causes enhancement of AMPAR-EPSCs and the AMPAR/NMDAR ratio in the VTA.

Next we examined whether Epac and PKA agonists altered the $\mathrm{RI}$ in the VTA. Whole-cell recordings were made with control internal solution or internal solution containing 8-CPT (100 $\mu \mathrm{M})$ or 6-Bnz-cAMP $(100 \mu \mathrm{M}) .8$-CPT is known to activate Epac but not PKA (Enserink et al., 2002). Nevertheless, we examined whether PKA was involved in 8-CPT-induced increase in the RI in $\mathrm{Epac}^{+/+}$slices. Slices were treated with vehicle or the PKA inhibitor H89 (10 $\mu \mathrm{M})$ for at least $1 \mathrm{~h}$. We and others have shown that, under this condition, H89 was effective in blocking PKAmediated responses in VTA dopamine neurons (Pan et al., 2008) and hippocampal slices (Chevaleyre et al., 2007). A two-way
ANOVA showed that intracellular dialysis of different internal solutions significantly changed the $\mathrm{RI}\left(F_{(2,54)}=17.5, p<0.001\right)$, $\mathrm{H} 89$ treatment had no significant effects on $\mathrm{RI}\left(F_{(1,54)}=0.7, p=\right.$ $0.399)$, and there was no significant interaction between internal solution and $\mathrm{H} 89$ treatment $\left(F_{(2,54)}=0.3, p=0.753\right.$; Fig. $\left.7 D\right)$. A priori (planned) comparisons indicate that 8 -CPT significantly increased the RI $(p=0.002)$, and $\mathrm{H} 89$ did not alter the RI ( $p=$ $0.941)$ or 8 -CPT ( $p=0.347)$-induced increase in the RI. 6-BnzcAMP did not alter the RI $(p=0.276$; Fig. $7 D)$. These results indicate that acute activation of Epac, but not PKA, significantly changes the RI in the VTA.

\section{Effects of Epac deletion on cocaine CPP, RI, and AMPAR/ NMDAR ratio in the VTA}

The dopamine neurons in the VTA and sustantia nigra sense reward and reward-predicting contextual cues (Schultz, 2002) and are likely involved in drug-cue associative learning (for review, see Kauer, 2004). We examined whether CPP to cocaine was regulated by Epac. $\mathrm{Epac}^{+/+}, \mathrm{Epac1}^{-/-}, \mathrm{Epac2}^{-/-}$, and $\mathrm{Epac}^{-/-}$mice underwent saline and cocaine conditioning. Five mice that exhibited unconditioned place preference $(\geq 180 \mathrm{~s})$ during the pretest were excluded from additional experiments. The remaining mice did not exhibit a significant difference in the time spent in each chamber $(p>0.05 ;$ Fig. $8 A)$. Then, cocaine (15 
A

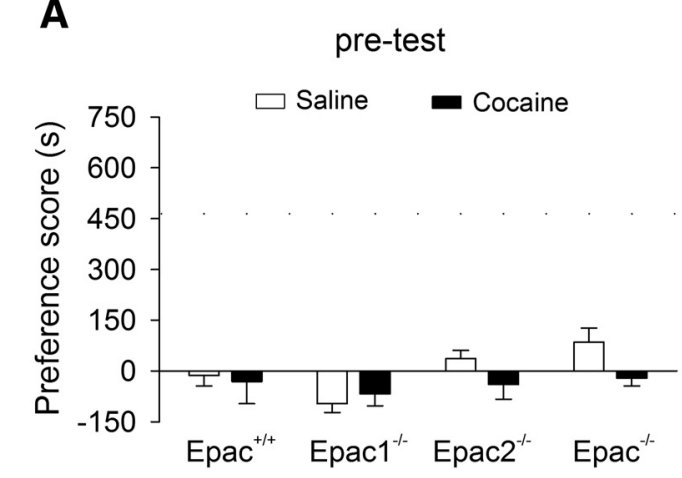

B

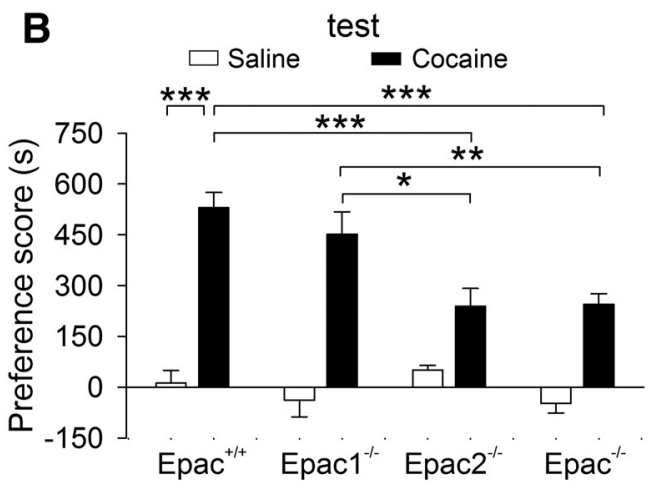

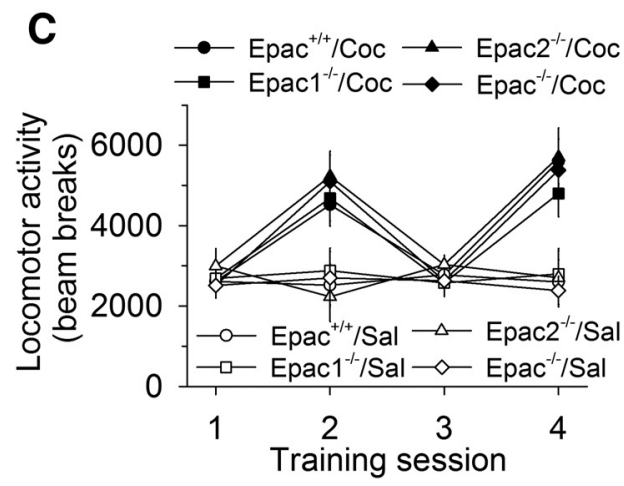
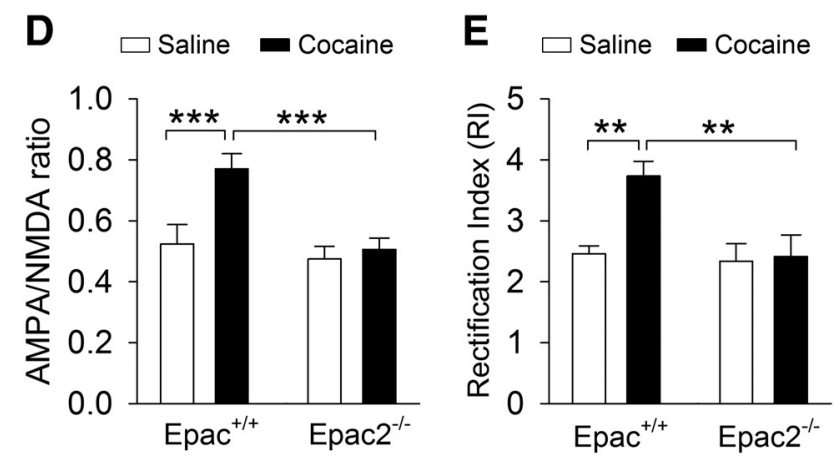

Figure 8. Cocaine CPP was impaired in Epac2- but not Epac1-deficient mice. $A, E p a C^{+/+}, \mathrm{Epac1}^{-/-}, \mathrm{Epac}^{-/-}$, and Epac ${ }^{-/-}$mice exhibited no significant unconditioned preference in each chamber during pretest $(p>0.05 ; n=8-14) . B$, Compared with that of wild-type Epac ${ }^{+/+}$mice, Epac ${ }^{-/-}$and Epac2 ${ }^{-/-}$mice exhibited significant decreases in the preference score $\left(^{*} p<0.05\right.$, ${ }^{* *} p<0.01$, $\left.{ }^{* * *} p<0.001 ; n=8-14\right)$; there was no significant change of the preference score in Epac1 ${ }^{-1-}$ mice $(p>0.05 ; n=9-12)$. C, Compared with saline (Sal), cocaine (Coc) significantly increased locomotor activity over the $2 \mathrm{~d}$ of place conditioning ( $\left.{ }^{* *} p<0.001 ; n=8-14\right)$, and the locomotor activity were not significantly different among different genotypes $(p=0.566$; $n=8-14)$. D, Cocaine injection in vivo significantly increased the AMPAR/NMDAR ratio in Epac ${ }^{+/+}$slices $\left({ }^{* * *} p<0.001 ; n=6-8\right)$, although this increase was blocked in Epac2 ${ }^{-/-}$ slices $\left.{ }^{* * *} p<0.001 ; n=7-8\right)$. E, Cocaine injection in vivo significantly increase the RI in Epac ${ }^{+/+}$slices $\left(^{* * *} p<0.001 ; n=6-7\right)$, although this increase was blocked in Epac2 ${ }^{-/-}$ slices $\left({ }^{* *} p<0.001 ; n=6-7\right)$.

$\mathrm{mg} / \mathrm{kg}$, i.p.) or saline place conditioning was conducted twice daily for $2 \mathrm{~d}$ (see Materials and Methods). Twenty-four hours after the last pairing, CPP was tested without any drug or vehicle administration. Two-way ANOVA revealed that genotype $\left(F_{(3,76)}\right.$ $=5.8, p=0.001)$ and cocaine $\left(F_{(1,76)}=136.7, p<0.001\right)$ had significant effects on the preference score, and there was a significant interaction between genotype and cocaine conditioning $\left(F_{(3,76)}=5.4, p=0.002\right.$; Fig. $\left.8 B\right)$. Tukey's post hoc tests showed that, in cocaine conditioning groups, Epac2 ${ }^{-/-}(p<0.001)$ and $\mathrm{Epac}^{-1-}(p<0.001)$ mice, but not Epacl ${ }^{-1-}$ mice $(p=0.557)$, displayed significant decreases in the preference score compared with the $\mathrm{Epac}^{+/+}$mice. In saline conditioning groups, the preference score was not significantly different among the four groups of mice $(p>0.05)$.

During place conditioning, locomotor activity in the conditioning chambers were tracked by infrared photobeam breaks. We compared locomotor activity in saline or cocaine conditioned wild-type and Epac knock-out mice over the $2 \mathrm{~d}$ of cocaine conditioning or corresponding saline conditioning (i.e., sessions 2 and 4). Locomotor activity were analyzed with a mixed ANOVA that included between-subjects factors of place conditioning and genotype and the within-subject factor of conditioning sessions. Cocaine conditioning significantly increased locomotor activity over the $2 \mathrm{~d}$ of place conditioning $\left(F_{(1,153)}=64.9, p<0.001\right)$, locomotor activity was not significantly different among different genotypes $\left(F_{(3,153)}=0.7, p=\right.$ $0.566)$, and there was no significant interaction between place conditioning and genotypes $\left(F_{(3,153)}=0.6, p=0.637\right.$; Fig. $\left.8 C\right)$.
Thus, cocaine-induced increases in locomotor activity were not significantly different among different genotypes. These results suggest that the reduction of CPP scores in Epac2 $2^{-1-}$ and Epac ${ }^{-1-}$ mice could not be attributed to the secondary consequence of changes in locomotor activity.

We have shown previously that a single cocaine injection in vivo led to changes in the AMPAR/NMDAR ratio and RI in VTA slices prepared from juvenile mice. Here we examined whether the AMPAR/NMDAR ratio and RI were changed in adult $\mathrm{Epac}^{+/+}$and $\mathrm{Epac2}^{-/-}$mice that underwent saline or cocaine conditioning and the CPP test. One day after the CPP test, the mice were killed and midbrain slices were prepared. The AMPAR/NMDAR ratio and RI were measured in VTA slices prepared from these four groups of mice. We found that genotype and cocaine conditioning had significant effects on the AMPAR/NMDAR ratio (genotype, $F_{(1,27)}=18.3, p<$ 0.001 ; cocaine conditioning, $\left.F_{(1,27)}=15.2, p<0.001\right)$ and RI (genotype, $F_{(1,25)}=7.2, p=0.013$; cocaine conditioning, $\left.F_{(1,25)}=6.4, p=0.019\right)$. There were significant interactions between cocaine conditioning and genotype for the AMPAR/ NMDAR ratio $\left(F_{(1,27)}=10.4, p=0.004\right.$; Fig. $\left.8 D\right)$ and RI $\left(F_{(1,25)}=5.0, p=0.035\right.$; Fig. $\left.8 E\right)$. Tukey's post hoc tests showed that the AMPAR/NMDAR ratio $(p<0.001)$ and $\mathrm{RI}(p=$ 0.003 ) in $\mathrm{Epac}^{+/+}$slices were significantly increased in the cocaine-conditioned group compared with the salineconditioned group, whereas these two parameters in $\mathrm{Epac2}^{-/-}$slices were not significantly different in the cocaine- 
A

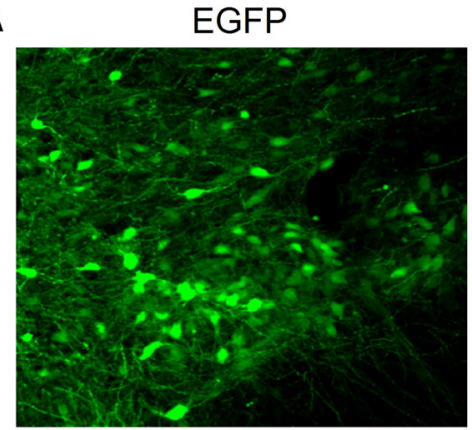

B

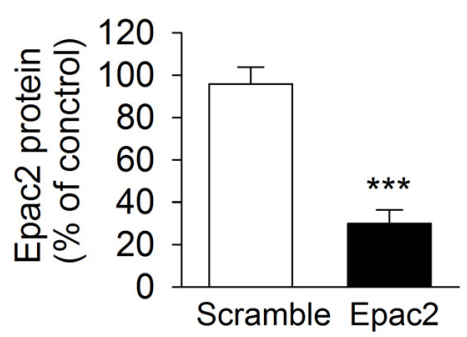

E

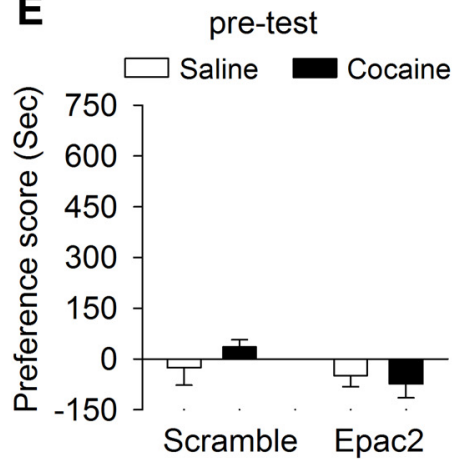

$\mathrm{TH}$

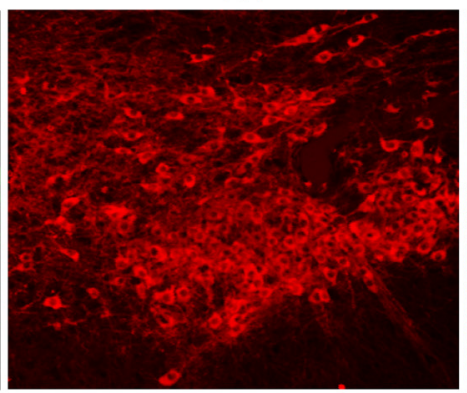

C

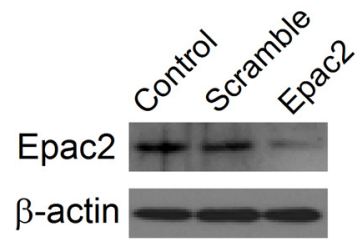

$\mathbf{F}$

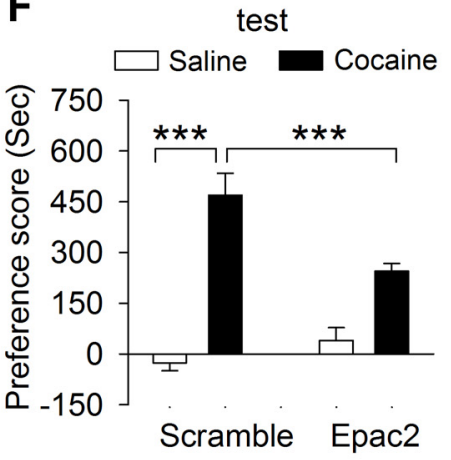

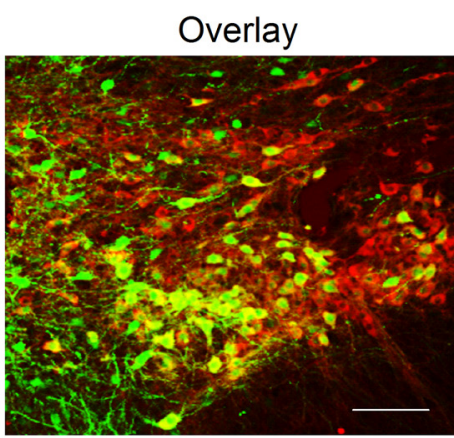

D

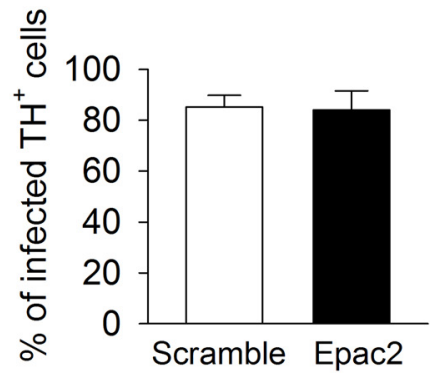

G

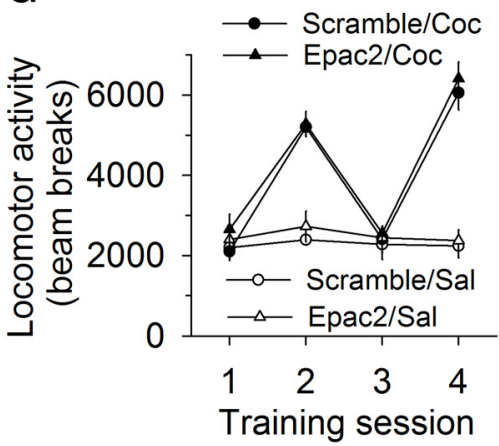

Figure 9. ShRNA knockdown of Epac2 in the VTA in wild-type mice attenuated cocaine CPP. $A$, Coexpression of TH (dopamine neuron marker, red) and AAV2-Epac2-shRNA-EGFP (green) in the midbrain. AAVs infected the majority of $\mathrm{TH}^{+}$dopamine neurons in the VTA. Scale bar, $100 \mu \mathrm{m}$. $\boldsymbol{B}$, Summarized data showed the percentage of TH ${ }^{+}$dopamine neurons infected with AAV2scramble-shRNA-EGFP or AAV2-Epac2-shRNA-EGFP ( $n=3$ mice per group). $\boldsymbol{C}, \boldsymbol{D}$, Representative $(\boldsymbol{C})$ and summarized ( $\boldsymbol{D})$ Western blots data showed that Epac2-shRNA, but not scrambleshRNA, reduced Epac2 levels in the VTA ( ${ }^{* * *} p<0.001 ; n=4$ mice each group). $\boldsymbol{E}$, Control mice (without AAV injections) and mice that received intra-VTA injections of AAV2-Epac2-shRNA-EGFP or AAV2-scramble-shRNA-AAV2-EGFP exhibited no unconditioned place preference during the pretest ( $p>0.05 ; n=8-9$ mice). $\boldsymbol{F}$, The preference score was significantly decreased in AAV2-Epac2-shRNA-EGFP-injected mice compared with AAV2-scramble-shRNA-EGFP-injected mice or wild-type mice $\left({ }^{* * *} p<0.001 ; n=8-9\right)$. G, Cocaine $(C o c)$ significantly increased locomotor activity over the $2 \mathrm{~d}$ of place conditioning ( $\left.{ }^{* * *} p<0.001 ; n=8-9\right)$, and the locomotor activity was not significant between the Epac2-shRNA and scramble-shRNA groups ( $p>0.05$; $n=8-9)$.

conditioned group compared with the saline-conditioned group ( $p>0.05$; Fig. $8 D, E)$.

We next determined whether Epac2 in the VTA was required for cocaine CPP. We stereotaxically injected AAV2 carrying scramble-shRNA or Epac2-shRNA with an EGFP reporter into the VTA bilaterally in wild-type $\left(\mathrm{Epac}^{+/+}\right)$mice. AAV2-scramble-shRNA-EGFP was expressed in $85.1 \pm 4.6 \%$ of $\mathrm{TH}^{+}$dopamine neurons in the VTA, whereas AAV2-Epac2-shRNA-EGFP was expressed in $84.0 \pm 7.6 \%$ of $\mathrm{TH}^{+}$dopamine neurons, as shown by colabeling of EGFP with $\mathrm{TH}$, a marker for dopamine neurons, in the VTA (Fig. 9A, $B, n=3$ mice per group). Approximately $25 \%$ of EGFP neurons were not colabeled with TH, suggesting that a substantial number of non-dopamine neurons were also infected by the AAVs (Fig. 9A). The Western blot of the VTA indicates that Epac2-shRNA $\left(t_{(7)}=6.4, p<0.001\right)$, but not scramble-shRNA, significantly reduced Epac2 levels in the VTA (Fig. 9C,D). Thus, Epac2-shRNA was effective in knocking down Epac2 in the VTA. We next determined whether knockdown of
Epac2 in the VTA affected cocaine CPP. Three weeks after the AAV injection, mice underwent cocaine conditioning as described above. Mice did not exhibit unconditioned place preference during the pretest $(p>0.05$; Fig. 9E). Two-way ANOVA revealed that shRNA $\left(F_{(1,32)}=7.3, p=0.011\right)$ and cocaine conditioning $\left(F_{(1,32)}=31.7, p<0.001\right)$ had significant effects on the preference score, and there was a significant interaction between shRNA and cocaine conditioning $\left(F_{(1,32)}=18.4, p<0.001\right.$; Fig. $9 F)$. Tukey's post hoc tests showed that Epac2-shRNA knockdown of Epac2 significantly decreased the preference score compared with the scramble-shRNA group ( $p<0.001$; Fig. $9 F)$. These results indicate that Epac2 signaling in the VTA is involved in CPP to cocaine.

We compared locomotor activity recorded in the conditioning chambers over the $2 \mathrm{~d}$ of cocaine conditioning or corresponding saline conditioning (i.e., sessions 2 and 4). Locomotor activity were analyzed with a mixed ANOVA that included between- 
subjects factors of place conditioning and shRNA and the withinsubject factor of conditioning sessions. Cocaine conditioning significantly increased locomotor activity over the $2 \mathrm{~d}$ of place conditioning $\left(F_{(1,65)}=102.7, p<0.001\right)$, and locomotor activity was not significantly different between the Epac2-shRNA and scramble-shRNA groups $\left(F_{(1,65)}=1.3, p=0.269\right)$. There was no significant interaction between place conditioning and shRNA $\left(F_{(1,65)}=0.1, p=0.984\right.$; Fig. $\left.9 G\right)$. Thus, Epac2 knockdown did not significantly alter the cocaine-induced increase in locomotor activity.

\section{Discussion}

A single cocaine injection in vivo induces an increase in GluA2lacking AMPARs in VTA dopamine neurons (Bellone and Lüscher, 2006; Argilli et al., 2008; Mameli et al., 2009; Good and Lupica, 2010), but the downstream mechanisms for cocaineinduced change in AMPAR subunit composition remains essentially unknown. Here, we have shown that genetic deletion of Epac2 blocked the cocaine-induced increase in GluA2-lacking AMPARs in the VTA, whereas the activation of Epac with 8-CPT mimicked the effect of cocaine in increasing GluA2-lacking AMPARs. These results suggest that Epac is required for the cocaine-induced change in AMPAR subunit composition in the VTA.

\section{Epac2 is required for cocaine-induced change in AMPAR subunit composition}

We showed that a single intraperitoneal cocaine injection led to an increase in the RI in Epac ${ }^{+/+}$and $\mathrm{Epacl}^{-/-}$slices ex vivo but not in $\mathrm{Epac}^{-/-}$and $\mathrm{Epac2}^{-/-}$slices. EPSCs were greatly attenuated by the selective GluA2-lacking AMPAR blocker Naspm in $\mathrm{Epac}^{+/+}$slices but were not significantly affected by Naspm in $\mathrm{Epac}^{-1-}$ slices. Cocaine $\mathrm{CPP}$ also caused an increase in the RI in $\mathrm{Epac}^{+/+}$mice but not in Epac2 ${ }^{-/}$mice. Furthermore, the selective Epac agonist 8-CPT mimicked the effect of the cocaineinduced increase in GluA2-lacking AMPARs in the VTA, and the effects of 8-CPT were dependent on Epac2. EPSCs recorded from 8-CPT-filled neurons in $\mathrm{Epac}^{+/+}$slices showed increases in the RI and sensitivity to Naspm blockade, but such increases were absent in Epac2 ${ }^{-1-}$ slices. Together, these results suggest a critical role of Epac2 in mediating the cocaine-induced change in AMPAR subunit composition. Epac2 is abundantly expressed in the brain, whereas Epac1 expression in the brain is very low (Kawasaki et al., 1998; de Rooij et al., 1998), which may explain why the Epac2 knock-out, but not the Epac1 knock-out alone, blocked the cocaine-induced increase in GluA2-lacking AMPARs.

How might Epac activation lead to an increase in GluA2lacking AMPARs in VTA dopamine neurons? Two possibilities may account for such increase: (1) the replacement of native GluA2-containing AMPARs with GluA2-lacking AMPARs; or (2) the insertion of GluA2-lacking AMPARs on top of existing AMPARs (Bellone and Lüscher, 2006). Epac proteins activate Rap1 and Rap2 (Kawasaki et al., 1998; de Rooij et al., 1998). Rap can activate p38 MAPK (Sawada et al., 2001), which leads to the removal of synaptic AMPARs containing short cytoplasmic tails, i.e., GluA2 and GluA3 (Zhu et al., 2002; Ster et al., 2009). We have shown that p38 MAPK inhibitors blocked the 8-CPT-induced increase in the RI in VTA dopamine neurons, suggesting that the Epac agonist causes the removal of GluA2-containing receptors from the cell surface. This notion appears to be supported by pharmacological intervention that selectively blocks the endocy- tosis of GluA2-containing AMPRs. The C terminus of GluA2 AMPARs interact with PDZ proteins, including PICK1; binding of PICK1 with the $\mathrm{C}$ terminus of GluA2 promotes internalization of GluA2-containing AMPARs (Collingridge et al., 2004). An interference peptide, Pep2-EVKI, disrupts the interaction of PICK1 with the $\mathrm{C}$ terminus of GluA2 and therefore blocks the endocytosis of GluA2 (Banke et al., 2000; Esteban et al., 2003). Localized viral vector delivery of Pep2-EVKI into the VTA blocked the increases in the RI and AMPAR/NMDAR ratio induced by a single cocaine exposure in vivo (Bellone and Lüscher, 2006). We showed that intracellular dialysis of Pep2-EVKI into VTA dopamine neurons did not alter RI by itself but blocked 8-CPT-induced increase in the RI, whereas the inactive control peptide Pep2-SVKE did not have a significant effect. Together, the above results suggest that in vivo cocaine exposure activates Epac to cause the replacement of native GluA2-containing AMPARs with GluA2-lacking AMPARs.

A single cocaine exposure in vivo leads to increases in the AMPAR/NMDAR ratio (Ungless et al., 2001; Borgland et al., 2004; Liu et al., 2005; Bellone and Lüscher, 2006; Argilli et al., 2008; Mameli et al., 2009) and AMPAR-mEPSCs and currents (Ungless et al., 2001). The present study showed the increases in the AMPAR/NMDAR ratio, and mEPSCs induced by a single cocaine exposure in vivo remained intact in $\mathrm{Epac}^{+/+}$mice but was blocked in Epac2 ${ }^{-1-}$ mice. Importantly, cocaine CPP led to Epacdependent increases in the AMPAR/NMDAR ratio and RI. These studies suggest that an increase in AMPAR-EPSCs contributes to the increase in the AMPAR/NMDAR ratio. Using two-photon laser uncaging of caged glutamate to evoke unitary NMDAR and AMPAR EPSCs in VTA dopamine neurons, recent studies have shown that in vivo cocaine exposure leads to a decrease in unitary NMDAR-EPSCs and an increase in AMPAR-EPSCs, suggesting that both increased AMPAR-EPSCs and reduced NMDAREPSCs contribute to the increase in the AMPAR/NMDAR ratio (Mameli et al., 2011; Yuan et al., 2013).

We examined the effects of intracellular application of Epac and PKA activators on EPSCs and the AMPAR/NMDAR ratio in the VTA. We found that 8-CPT caused a modest decrease in AMPAR-EPSCs and statistically insignificant change of the AMPAR/NMDAR ratio, the latter of which may be explained by a very modest change of AMPAR-EPSCs. Our results are consistent with previous studies showing that 8 -CPT induced removal of GluA2-AMPARs and long-term depression-like synaptic modification in cortical and hippocampal neurons (Ster et al., 2009; Woolfrey et al., 2009). In contrast, intracellular dialysis of the PKA activator 6-Bnz-cAMP caused robust increases in AMPAREPSCs and the AMPAR/NMDAR ratio. PKA-mediated phosphorylation of GluA1 S845 is known to promote GluA1 cell-surface insertion, increase AMPAR channel open probability, and facilitate the induction of LTP (Banke et al., 2000; Esteban et al., 2003; Man et al., 2007). The adenylyl cyclase activator forskolin potentiates EPSCs, whereas PKA inhibitors depress EPSCs in VTA dopamine neurons (Haj-Dahmane and Shen, 2010), although PKA-dependent depression of EPSCs was also reported in the VTA (Gutlerner et al., 2002). We suspect that activation of Epac causes the removal of GluA2-AMPARs from synapses in VTA dopamine neurons, whereas activation of PKA induces insertion of GluA1-AMPARs. The activation of the $\mathrm{D}_{1}$ dopamine receptor is required for cocaine-induced increases in GluA2-lacking AMPARs (Brown et al., 2010) and the AMPAR/ NMDAR ratio in the VTA (Argilli et al., 2008). Epac and PKA are downstream effectors of $D_{1}$ receptors. Although acute activation of Epac and PKA with 8-CPT and 6-Bnz-cAMP may not recapit- 
ulate conditions after in vivo cocaine exposure, our results suggest that both Epac and PKA are activated after in vivo cocaine exposure and act cooperatively to mediate cocaine-induced increases in the RI and AMPAR/NMDAR ratio, which may explain why such increases were blocked in Epac2 knock-out mice.

\section{Modulation of cocaine CPP by Epac}

Epac signaling has been implicated in learning and memory. Hippocampal Epac signaling is required for memory retrieval (Ouyang et al., 2008; Ostroveanu et al., 2010). Infusion of 8-CPT into the dorsal hippocampus enhances contextual fear and inhibitory avoidance, and siRNA knockdown of Epac2 in the dorsal hippocampus after (but not before) training impairs intermediateterm contextual fear memory (Ostroveanu et al., 2010). Dorsal hippocampal infusion of PKA and Epac agonists together, but not either agonist alone, rescues contextual memory retrieval in norepinephrine-deficient mice (Ouyang et al., 2008). Epac ${ }^{-1-}$ mice showed spatial learning and memory deficits in the Morris water maze test (Yang et al., 2012). A recent study has shown that intra-basolateral amygdala (BLA) infusion of 8-CPT immediately after reactivation of a drug-cue memory diminished cueinduced reinstatement of cocaine-seeking in rats, suggesting that Epac activation in the BLA inhibited drug-associated memory reconsolidation (Wan et al., 2014). Thus, Epac signaling in discrete brain regions may play distinct or even opposite roles in appetitive and aversive learning. In the present study, we examined whether Epac subtype knock-out altered cocaine CPP, which has a strong learning component. We have found that, compared with wild-type mice, cocaine CPP scores were significantly decreased in Epac2 ${ }^{-/-}$mice and $\mathrm{Epac}^{-/-}$mice but remained unchanged in Epac1 ${ }^{-1-}$ mice. Microinjections of PKA inhibitors into the VTA or intracerebroventricularly in the rat led to impairments of CPP to cocaine or amphetamine (Cervo et al., 1997; Ahn et al., 2010). Together, these studies suggest that both cAMP effectors are critically involved in drug-cue associative learning. One caveat of using knock-out mice is that Epac is deleted during early development, and not all of the behavioral effects of Epac deletion are necessarily attributable to the nullified gene itself. Gene knock-out may also induce compensatory changes. However, these concerns may be lessened by the finding that that shRNA knockdown of Epac2 in the VTA attenuated cocaine CPP.

In summary, we showed that genetic deletion of Epac2 blocked cocaine-induced increases in the RI and sensitivity of EPSCs to NASPM, whereas activation of Epac with 8-CPT recapitulated the effects of cocaine. These results uncovered a critical role of Epac in mediating cocaine-induced increase in GluA2-lacking AMPARs in VTA dopamine neurons. In addition, we demonstrated that cocaine CPP was impaired in Epac2 ${ }^{-/-}$and Epac ${ }^{-1-}$ mice and in mice in which Epac2 was knocked down in the VTA but remained unchanged in Epac1 ${ }^{-/-}$mice. Together, these studies reveal that Epac signaling is critical to cocaine-induced long-term synaptic plasticity and formation of cocaine-cue associative memories.

\section{References}

Ahn KC, Bernier BE, Harnett MT, Morikawa H (2010) IP3 receptor sensitization during in vivo amphetamine experience enhances NMDA receptor plasticity in dopamine neurons of the ventral tegmental area. J Neurosci 30:6689-6699. CrossRef Medline

Anderson SM, Pierce RC (2005) Cocaine-induced alterations in dopamine receptor signaling: implications for reinforcement and reinstatement. Pharmacol Ther 106:389-403. CrossRef Medline

Argilli E, Sibley DR, Malenka RC, England PM, Bonci A (2008) Mechanism and time course of cocaine-induced long-term potentiation in the ventral tegmental area. J Neurosci 28:9092-9100. CrossRef Medline

Banke TG, Bowie D, Lee H, Huganir RL, Schousboe A, Traynelis SF (2000) Control of GluR1 AMPA receptor function by cAMP-dependent protein kinase. J Neurosci 20:89-102. Medline

Bellone C, Lüscher C (2006) Cocaine triggered AMPA receptor redistribution is reversed in vivo by mGluR-dependent long-term depression. Nat Neurosci 9:636-641. CrossRef Medline

Bellone C, Lüscher C (2012) Drug-evoked plasticity: do addictive drugs reopen a critical period of postnatal synaptic development? Front Mol Neurosci 5:75. Medline

Bellone C, Mameli M, Lüscher C (2011) In utero exposure to cocaine delays postnatal synaptic maturation of glutamatergic transmission in the VTA. Nat Neurosci 14:1439-1446. CrossRef Medline

Borgland SL, Malenka RC, Bonci A (2004) Acute and chronic cocaineinduced potentiation of synaptic strength in the ventral tegmental area: electrophysiological and behavioral correlates in individual rats. J Neurosci 24:7482-7490. CrossRef Medline

Brown MT, Bellone C, Mameli M, Labouèbe G, Bocklisch C, Balland B, Dahan L, Luján R, Deisseroth K, Lüscher C (2010) Drug-driven AMPA receptor redistribution mimicked by selective dopamine neuron stimulation. PLoS One 5:e15870. CrossRef Medline

Cervo L, Mukherjee S, Bertaglia A, Samanin R (1997) Protein kinases A and $\mathrm{C}$ are involved in the mechanisms underlying consolidation of cocaine place conditioning. Brain Res 775:30-36. CrossRef Medline

Cheng X, Ji Z, Tsalkova T, Mei F (2008) Epac and PKA: a tale of two intracellular cAMP receptors. Acta Biochim Biophys Sin (Shanghai) 40: 651-662. CrossRef Medline

Chevaleyre V, Heifets BD, Kaeser PS, Südhof TC, Purpura DP, Castillo PE (2007) Endocannabinoid-mediated long-term plasticity requires cAMP/ PKA signaling and RIMlalpha. Neuron 54:801-812. CrossRef Medline

Chieng B, Azriel Y, Mohammadi S, Christie MJ (2011) Distinct cellular properties of identified dopaminergic and GABAergic neurons in the mouse ventral tegmental area. J Physiol 589:3775-3787. CrossRef Medline

Collingridge GL, Isaac JT, Wang YT (2004) Receptor trafficking and synaptic plasticity. Nat Rev Neurosci 5:952-962. CrossRef Medline

Conrad KL, Tseng KY, Uejima JL, Reimers JM, Heng LJ, Shaham Y, Marinelli M, Wolf ME (2008) Formation of accumbens GluR2-lacking AMPA receptors mediates incubation of cocaine craving. Nature 454:118-121. CrossRef Medline

de Rooij J, Zwartkruis FJ, Verheijen MH, Cool RH, Nijman SM, Wittinghofer A, Bos JL (1998) Epac is a Rap1 guanine-nucleotide-exchange factor directly activated by cyclic AMP. Nature 396:474-477. CrossRef Medline

Enserink JM, Christensen AE, de Rooij J, van Triest M, Schwede F, Genieser HG, Døskeland SO, Blank JL, Bos JL (2002) A novel Epac-specific cAMP analogue demonstrates independent regulation of Rap1 and ERK. Nat Cell Biol 4:901-906. CrossRef Medline

Esteban JA, Shi SH, Wilson C, Nuriya M, Huganir RL, Malinow R (2003) PKA phosphorylation of AMPA receptor subunits controls synaptic trafficking underlying plasticity. Nat Neurosci 6:136-143. CrossRef Medline

Gardner SM, Takamiya K, Xia J, Suh JG, Johnson R, Yu S, Huganir RL (2005) Calcium-permeable AMPA receptor plasticity is mediated by subunitspecific interactions with PICK1 and NSF. Neuron 45:903-915. CrossRef Medline

Gloerich M, Bos JL (2010) Epac: defining a new mechanism for cAMP action. Annu Rev Pharmacol Toxicol 50:355-375. CrossRef Medline

Good CH, Lupica CR (2010) Afferent-specific AMPA receptor subunit composition and regulation of synaptic plasticity in midbrain dopamine neurons by abused drugs. J Neurosci 30:7900-7909. CrossRef Medline

Gutlerner JL, Penick EC, Snyder EM, Kauer JA (2002) Novel protein kinase A-dependent long-term depression of excitatory synapses. Neuron 36: 921-931. CrossRef Medline

Haj-Dahmane S, Shen RY (2010) Regulation of plasticity of glutamate synapses by endocannabinoids and the cyclic-AMP/protein kinase A pathway in midbrain dopamine neurons. J Physiol 588:2589-2604. CrossRef Medline

Hewer RC, Sala-Newby GB, Wu YJ, Newby AC, Bond M (2011) PKA and Epac synergistically inhibit smooth muscle cell proliferation. J Mol Cell Cardiol 50:87-98. CrossRef Medline

Huang YH, Lin Y, Mu P, Lee BR, Brown TE, Wayman G, Marie H, Liu W, Yan Z, Sorg BA, Schlüter OM, Zukin RS, Dong Y (2009) In vivo cocaine 
experience generates silent synapses. Neuron 63:40-47. CrossRef Medline

Isaac JT, Ashby MC, McBain CJ (2007) The role of the GluR2 subunit in AMPA receptor function and synaptic plasticity. Neuron 54:859-871. CrossRef Medline

Johnson SW, North RA (1992) Two types of neurone in the rat ventral tegmental area and their synaptic inputs. J Physiol 450:455-468. CrossRef Medline

Kauer JA (2004) Learning mechanisms in addiction: synaptic plasticity in the ventral tegmental area as a result of exposure to drugs of abuse. Annu Rev Physiol 66:447-475. CrossRef Medline

Kawasaki H, Springett GM, Mochizuki N, Toki S, Nakaya M, Matsuda M, Housman DE, Graybiel AM (1998) A family of cAMP-binding proteins that directly activate Rap1. Science 282:2275-2279. CrossRef Medline

Kourrich S, Rothwell PE, Klug JR, Thomas MJ (2007) Cocaine experience controls bidirectional synaptic plasticity in the nucleus accumbens. J Neurosci 27:7921-7928. CrossRef Medline

Li P, Kerchner GA, Sala C, Wei F, Huettner JE, Sheng M, Zhuo M (1999) AMPA receptor-PDZ interactions in facilitation of spinal sensory synapses. Nat Neurosci 2:972-977. CrossRef Medline

Liu QS, Pu L, Poo MM (2005) Repeated cocaine exposure in vivo facilitates LTP induction in midbrain dopamine neurons. Nature 437:1027-1031. CrossRef Medline

Liu SJ, Cull-Candy SG (2005) Subunit interaction with PICK and GRIP controls $\mathrm{Ca} 2+$ permeability of AMPARs at cerebellar synapses. Nat Neurosci 8:768-775. CrossRef Medline

Mameli M, Balland B, Luján R, Lüscher C (2007) Rapid synthesis and synaptic insertion of GluR2 for mGluR-LTD in the ventral tegmental area. Science 317:530-533. CrossRef Medline

Mameli M, Halbout B, Creton C, Engblom D, Parkitna JR, Spanagel R, Lüscher C (2009) Cocaine-evoked synaptic plasticity: persistence in the VTA triggers adaptations in the NAc. Nat Neurosci 12:1036-1041. CrossRef Medline

Mameli M, Bellone C, Brown MT, Lüscher C (2011) Cocaine inverts rules for synaptic plasticity of glutamate transmission in the ventral tegmental area. Nat Neurosci 14:414-416. CrossRef Medline

Man HY, Sekine-Aizawa Y, Huganir RL (2007) Regulation of \{alpha\}amino-3-hydroxy-5-methyl-4-isoxazolepropionic acid receptor trafficking through PKA phosphorylation of the Glu receptor 1 subunit. Proc Natl Acad Sci U S A 104:3579-3584. CrossRef Medline

Neve KA, Seamans JK, Trantham-Davidson H (2004) Dopamine receptor signaling. J Recept Signal Transduct Res 24:165-205. CrossRef Medline

Ostroveanu A, van der Zee EA, Eisel UL, Schmidt M, Nijholt IM (2010) Exchange protein activated by cyclic AMP 2 (Epac2) plays a specific and time-limited role in memory retrieval. Hippocampus 20:1018-1026. CrossRef Medline

Ouyang M, Zhang L, Zhu JJ, Schwede F, Thomas SA (2008) Epac signaling is required for hippocampus-dependent memory retrieval. Proc Natl Acad Sci U S A 105:11993-11997. CrossRef Medline

Pan B, Hillard CJ, Liu QS (2008) D2 dopamine receptor activation facilitates endocannabinoid-mediated long-term synaptic depression of GABAergic synaptic transmission in midbrain dopamine neurons via cAMP-protein kinase A signaling. J Neurosci 28:14018-14030. CrossRef Medline

Paxinos G, Franklin KBJ (2001) The mouse brain in stereotaxic coordinates, Ed 2. San Diego: Academic.

Saal D, Dong Y, Bonci A, Malenka RC (2003) Drugs of abuse and stress trigger a common synaptic adaptation in dopamine neurons. Neuron 37:577-582. CrossRef Medline

Sawada Y, Nakamura K, Doi K, Takeda K, Tobiume K, Saitoh M, Morita K, Komuro I, De Vos K, Sheetz M, Ichijo H (2001) Rap1 is involved in cell stretching modulation of p38 but not ERK or JNK MAP kinase. J Cell Sci 114:1221-1227. Medline

Schmidt M, Dekker FJ, Maarsingh H (2013) Exchange protein directly acti- vated by cAMP (epac): a multidomain cAMP mediator in the regulation of diverse biological functions. Pharmacol Rev 65:670-709. CrossRef Medline

Schultz W (2002) Getting formal with dopamine and reward. Neuron 36: 241-263. CrossRef Medline

Srivastava DP, Jones KA, Woolfrey KM, Burgdorf J, Russell TA, Kalmbach A, Lee H, Yang C, Bradberry MM, Wokosin D, Moskal JR, Casanova MF, Waters J, Penzes P (2012) Social, communication, and cortical structural impairments in Epac2-deficient mice. J Neurosci 32:11864-11878. CrossRef Medline

Ster J, de Bock F, Bertaso F, Abitbol K, Daniel H, Bockaert J, Fagni L (2009) Epac mediates PACAP-dependent long-term depression in the hippocampus. J Physiol 587:101-113. CrossRef Medline

Tritsch NX, Sabatini BL (2012) Dopaminergic modulation of synaptic transmission in cortex and striatum. Neuron 76:33-50. CrossRef Medline

Tsubokawa H, Oguro K, Masuzawa T, Nakaima T, Kawai N (1995) Effects of a spider toxin and its analogue on glutamate-activated currents in the hippocampal CA1 neuron after ischemia. J Neurophysiol 74:218-225. Medline

Ungless MA, Whistler JL, Malenka RC, Bonci A (2001) Single cocaine exposure in vivo induces long-term potentiation in dopamine neurons. Nature 411:583-587. CrossRef Medline

Vialou V, Feng J, Robison AJ, Ku SM, Ferguson D, Scobie KN, Mazei-Robison MS, Mouzon E, Nestler EJ (2012) Serum response factor and cAMP response element binding protein are both required for cocaine induction of DeltaFosB. J Neurosci 32:7577-7584. CrossRef Medline

Wan X, Torregrossa MM, Sanchez H, Nairn AC, Taylor JR (2014) Activation of exchange protein activated by cAMP in the rat basolateral amygdala impairs reconsolidation of a memory associated with selfadministered cocaine. PLoS One 9:e107359. CrossRef Medline

Woolfrey KM, Srivastava DP, Photowala H, Yamashita M, Barbolina MV, Cahill ME, Xie Z, Jones KA, Quilliam LA, Prakriya M, Penzes P (2009) Epac2 induces synapse remodeling and depression and its diseaseassociated forms alter spines. Nat Neurosci 12:1275-1284. CrossRef Medline

Yang Y, Shu X, Liu D, Shang Y, Wu Y, Pei L, Xu X, Tian Q, Zhang J, Qian K, Wang YX, Petralia RS, Tu W, Zhu LQ, Wang JZ, Lu Y (2012) EPAC null mutation impairs learning and social interactions via aberrant regulation of miR-124 and Zif268 translation. Neuron 73:774-788. CrossRef Medline

Yu F, Zhong P, Liu X, Sun D, Gao HQ, Liu QS (2013) Metabotropic glutamate receptor I (mGluR1) antagonism impairs cocaine-induced conditioned place preference via inhibition of protein synthesis. Neuropsychopharmacology 38:1308-1321. CrossRef Medline

Yuan T, Mameli M, O'Connor EC, Dey PN, Verpelli C, Sala C, Perez-Otano I, Lüscher C, Bellone C (2013) Expression of cocaine-evoked synaptic plasticity by GluN3A-containing NMDA receptors. Neuron 80 : 1025-1038. CrossRef Medline

Zhong P, Wang W, Yu F, Nazari M, Liu X, Liu QS (2012) Phosphodiesterase 4 inhibition impairs cocaine-induced inhibitory synaptic plasticity and conditioned place preference. Neuropsychopharmacology 37:2377-2387. CrossRef Medline

Zhong P, Liu Y, Hu Y, Wang T, Zhao YP, Liu QS (2015) BDNF interacts with endocannabinoids to regulate cocaine-induced synaptic plasticity in mouse midbrain dopamine neurons. J Neurosci 35:4469-4481. CrossRef Medline

Zhu JJ, Qin Y, Zhao M, Van Aelst L, Malinow R (2002) Ras and Rap control AMPA receptor trafficking during synaptic plasticity. Cell 110:443-455. CrossRef Medline

Zhu PJ, Lovinger DM (2005) Retrograde endocannabinoid signaling in a postsynaptic neuron/synaptic bouton preparation from basolateral amygdala. J Neurosci 25:6199-6207. CrossRef Medline

Zucker RS, Regehr WG (2002) Short-term synaptic plasticity. Annu Rev Physiol 64:355-405. CrossRef Medline 